\begin{tabular}{|c|c|c|}
\hline ב & $\begin{array}{l}\text { International Journal of Current Research in } \\
\text { Biosciences and Plant Biology }\end{array}$ & $=$ \\
\hline & Volume $7 \bullet$ Number 4 (April-2020) • ISSN: 2349-8080 (Online) & \\
\hline $\begin{array}{l}\text { EXCELLENT } \\
\text { PUBLISHERS }\end{array}$ & Journal homepage: $\underline{w w w . i j c r b p . c o m}$ & \\
\hline
\end{tabular}

\title{
Characterization of plant groups and description of plant succession in the sacred Kouoghap forest of the Batoufam village, West Cameroon
}

\author{
Junelle Makemteu1* and Emmanuel Noumi² \\ ${ }^{1}$ Department of Pharmaceutical Sciences, Faculty of Medicine and Pharmaceutical Sciences, \\ University of Dschang, P. O. Box 96 Dschang, Cameroon \\ ${ }^{2}$ Laboratory of Plant Biology: Higher Teachers' Training College, University of Yaounde I, \\ P. O. Box 47, Yaounde, Cameroon \\ ${ }^{*}$ Corresponding author; e-mail: junellecoposa2014@gmail.com
}

\begin{tabular}{|c|c|}
\hline $\mathbf{A}$ & B \\
\hline $\begin{array}{l}\text { Date of Acceptance: } \\
\text { o3 March } 2020\end{array}$ & \multirow{5}{*}{$\begin{array}{l}\text { The Batoufam village located in the mountaineous Western Region of Cameroon, forms } \\
\text { part of the bioclimatic zone of the northern peripheral domain of the Guineo-Congolese } \\
\text { region of Cameroon Guineo-Congolese phytogeographic region. This region is known } \\
\text { for its bocager landscape. In this village, the Kouoghap gallery forest is remnants of the } \\
\text { pioneer vegetation destroyed by man which has been conserved because of its sacred } \\
\text { nature. This work is a phytosociological analysis of the Kouoghap forest and an } \\
\text { assessment of its floristic affinities with other central Africa and Neotropical forest } \\
\text { sites. The phytosociological analysis was based on the comparison of the } 265 \text { plant } \\
\text { species lists within an area of o.25-hestarest. The analyses of the floristic groupings } \\
\text { have been made on the basis of the partition of the samples by Detrended } \\
\text { Correspondence Analysis (DCA) and an Ascending Hierarchical Classification (CHA). } \\
\text { The Kouoghap forest presents three major plant sets: the gallery forest, the rainforest } \\
\text { and one of the various groupings. Two submontane forests were described as two plant } \\
\text { associations: the Synsepalum cerasiferum ass. nov. of the forest galleries of the } \\
\text { northern domain of the Guineo-Congolese region, and the Tricalysietum macrophyllae } \\
\text { ass. nov. of the rainforest. The flora of Kouoghap counts a strong proportion of both } \\
\text { the guineo - Congolese species (at least } 51 \% \text { ) and Soudano-Zambezian (at least } 13 \% \text { ). }\end{array}$} \\
\hline & \\
\hline Keywords & \\
\hline ntane & \\
\hline & \\
\hline
\end{tabular}

\section{Introduction}

Batoufam $\left(5^{\circ} 14^{\prime}-5^{\circ} 18 \mathrm{~N}\right.$ latitude and $10^{\circ} 26^{\prime}-10^{\circ} 31^{\prime} \mathrm{E}$ longitude) is a village of the highlands of the Western Region of Cameroon. The survey site has an altitude of 1400-1500 m, at the northern limits of the dense continuous forest that covers the Cameroonian south plateau (Kuété, 1977), to the zone of confrontation of the two masses of air: the
Mousson of the equatorial climate in the south and the Harmattan of the tropical climate in the north.

Though the phytogeographic aspect of different forests at the high summits have been studied (Noumi, 2013; Tchoua, 2013) as well as the photosociologic aspect (Noumi, 1998; Noumi and Amougou, 2003; Noumi, 2012) the summit forests remaindless explored. Koechlin and Trochain (1955) 
described the succession the rainforest and the semideciduous forest without an intermediate stage of savanna, according to the climatic, edaphic and biotic local conditions.

The sacral Kouoghap forest situated on the southern slope of the valley between the Famla and Fieutchip quarters of the Batoufam village, drained by the Lioglok River, is a valley forest. It is an edaphic and physiographic grouping, because it benefits from a favorable microclimate due to the constriction of the sides of the valley. It is therefore a "gallery forest". This survey will permit to explore the sociology between the different types of plant formation and maybe to consider the hypothesis of the succession rainforest-gallery forest. This study is motivated by the fact that this forest is a representation of the vegetation of yesteryear in the highlands of the west Cameroon which has been destroyed by the human activities.

\section{Materials and methods}

\section{Study area}

Batoufam is nested in the south side of the Batoufam-Bayangam caldeira on a surface of 27 $\mathrm{km}^{2}$. The cavity opens up to the North-east which by passes the rivers and tributaries of the Koupa that flows into the Noun River (Fig. 1).

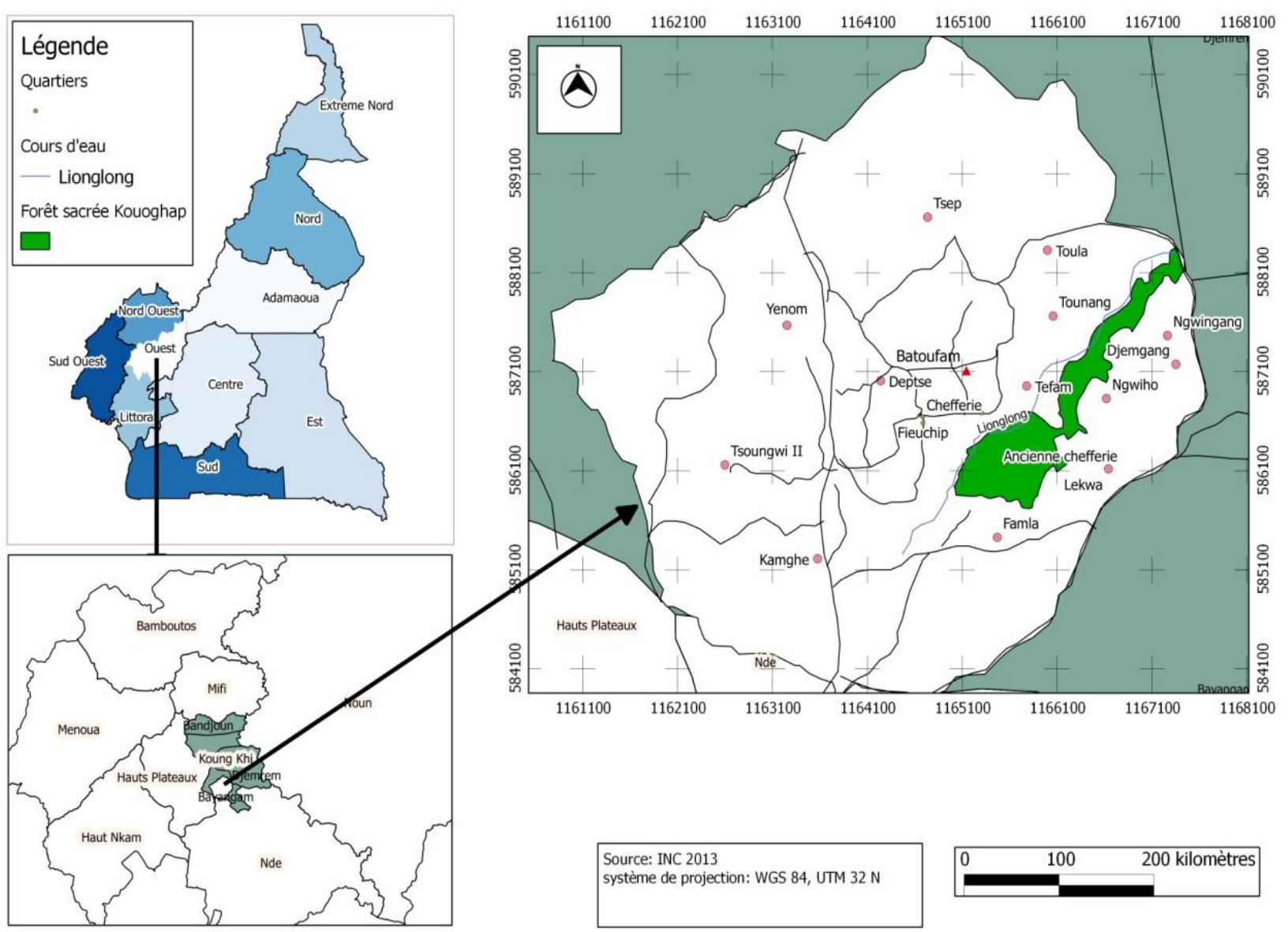

Fig. 1: Map of the location of Batoufam and the botanical landscape of the Kouoghap Forest.

Inside the caldeira three damaged terraces were established at an elevation of 1400, 1600 and 1800m, respectively (Fosso, 1999). They are separated by two layers eased by the erosion, of which the lowest (between 1400 and 1600m) is located in the Kouoghap Forest, on the south- eastern side. The Bangou volcano presents itself like an enormous stratovolcan whose lavas rest on a substratum constituted of intrusive granites in metamorphic formations (gneiss, migmatiques and matexites) belonging to the north equatorial PanAfrican range (Nzenti et al., 1992). Ferruginous 
soils have developed on the volcanic products, characterized more or less by the abundance of the fragments of deteriorating basalt (Tchoua, 1974; Njiki, 1984; Letouzey, 1968).

Batoufam belongs to the bioclimatic zone of the mountains and high lands of West Cameroon, the submountain domain of the Guinean-Congolese phytogeographic region (Letouzey, 1968). The temperatures are curbed and the thermal amplitudes are big (Ducret, 1990). The yearly average temperature is $19.32^{\circ} \mathrm{C}$. The Bamiléké plateau is submitted to the humid wind (monsoon) coming from the Atlantic Ocean, and to the incursions of the tropical air of the Sahara (Harmattan). The meeting of these two masses of air forms the Inter Tropical Forehead (ITF) whose swing determines the cycle of the seasons. The yearly rainfall varies from 1238.3 to $1838 \mathrm{~mm}$, with a yearly average of $1627.9 \mathrm{~mm}$. The climate is tropical, with 2 seasons: a dry season from November to February and a season of the rains from March to October (Suchel, 1972) (Fig. 2).

The total population estimated to 30 ooo is $99 \%$ native, practicing traditional agriculture for a living. The highland landscape presents summit hills covered with grassy savanna, then of the sacred woods, frequent in many concessions.

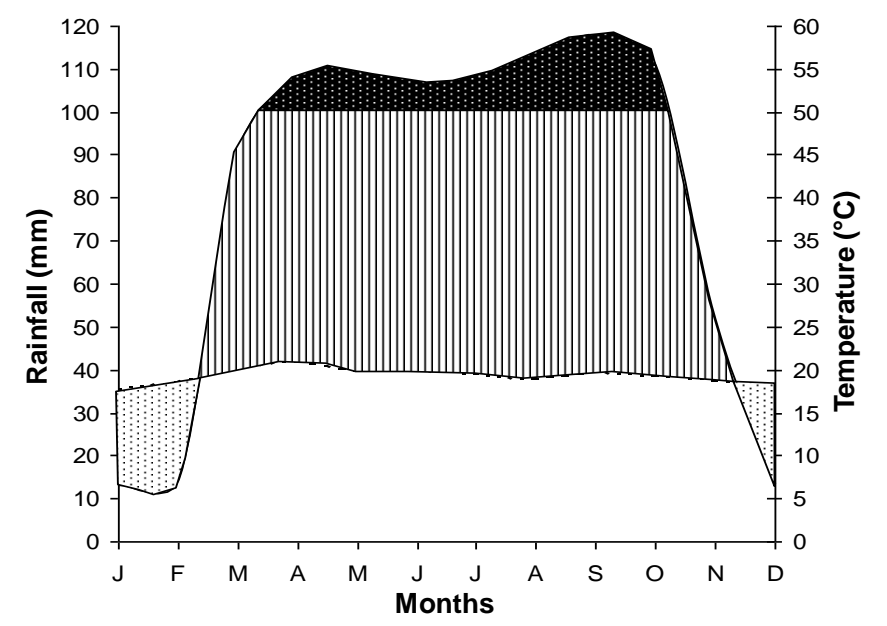

Fig. 2: Ombro-thermic diagram. Curve of the monthly mean of rainfalls [scale reduced to the $1 / 10$ from10o $\mathrm{mm}$, gray part, according to the method of Walter and Lieth (1964) and of the monthly mean of temperature. Data of the meteorological station of BafoussamBamougoum, 1991 to 2012. There are no monthly mean values of precipitation and temperature in Batoufam, but these values must be nearest of those of BafoussamBamougoum Station situated at $20 \mathrm{~km}$ of the North side. -Very humid period, over $100 \mathrm{~mm}$; $\Pi \pi \mathrm{T}$ Humid period; $\ldots$ - Biologically dry period.

\section{Methodology}

The survey is sustained by the theory according to which " the visible elements of vegetation are the indicators that permit to have visions of the facts or phenomena that took place before the present stage (Noumi, 2008). A quantitative inventory of a 2.5-ha surface was achieved by rectangular plots (25 $\mathrm{m}$ of width on $100 \mathrm{~m}$ of length), taking into account all the vascular plant species (trees, herbs and lianas) in 2014-2015.

The determination of big tree, inaccessible at the harvests, was made in situ using the dendrological criteria (Normand, 1965; Vivien and Faure, 1985). The 45 samples harvested and dried were identified using some volumes of floras and documentation (Aubreville et al., 1961-1999; Aubreville et al., 1963-1998; Lebrun and Stork, 1191, 1992, 1995, 1997). Thereafter, the identified samples were compared with those specimens preserved at the National herbarium of Cameroon (YA), of the Ministry of the Scientific and Technical Research, for verification. The constituted herbaria were kept in the Laboratory of Plant Biology of the Higher Teacher Training College of the University of Yaoundé I.

The synthetic features of flora were considered in a synthetic manner through the main physiognomic spectra. The biologic types (BT) were distinguished according to many authors (Raunkiaer, 1934; Ellemberg and Mueller-Dombois, 1967; Boquet and Aeschimann, 1981; Schnell, 1971). The types of diaspores are determined using some classification (Danserau and Lems, 1957; Evrard, 1968).

Their phytogeographic distribution types (TP) were established according to the works for the intertropical massif orophytes (Schnell, 1970) for the big chorological subdivisions of Africa (White, 1983) and for the phytogeography of Cameroon (Letouzey, 1985). The phytosociologic units (PU) were based onsome classifications (Noumi, 1998; Lebrun and Gilbert, 1954; Schmitz, 1988). The coverage of the species has been established according to the Braun-Blanquet (Braun-Blanquet, 
1932). To measure the specific diversity from a list of species and their number of individual partners, the Shannon index $\left(H^{\prime}\right)$ was used (Shannon and Weaver, 1949):

$$
\mathrm{ISH}=-\sum \mathrm{N}_{\mathrm{i}} / \mathrm{N} \log _{2} \mathrm{~N}_{\mathrm{i}} / \mathrm{N}
$$

Where, $\mathrm{Ni}$ is the strength of the species " $i$ " and $N$ the strength of all species. It is expressed in bits.

After the encoding of the data from the software Excel 2007, the lists of the species thus established were treated in a suitable manner. The presences (P) and middle coverage (RM) of species were used like first criteria of ordering in order to establish the typology of the samplings.

The «Detrended Correspondence Analysis» (DCA) techniques was used for the treatment of the data, which is an improvement of the Correspondence Factorial analysis method (AFC), a method that permits us to regroup clouds of similar samplings and by species. The ordination of the samplings was done using the Two Way Indicator Species Analysis software (Twinspan) (Hill, 1994).

The ascending hierarchical classification (CAH) is a powerful analysis method that permitted us to regroup the objects following a matrix of distance (the similarity in our case) between these objects (the summaries in our case).

The dendrogram obtained from the ascending hierarchical classification (CAH) was with the help of the Multi-Variate Statistical Package (MVSP 3.22) software using the method of Ward on the basis of the distance of Bray-Curtis, clustering by UPGMA. The factorial plans are gotten with the software MVSP 3.22 on the basis of a DCA.

\section{Results}

\section{Floristic composition}

The sacral forest Kouoghap is a fragment of forest grouping of high cluster that developed on the south side of the valley crossed by the Lionlong River. It is both an edaphic and physiographic grouping because it benefits from a favorable microclimate due to the roadbed of the valley and to the tributary of Lionlong River (Fig. 3). These conditions are therefore favourable for a gallery forest, for the growth of the trees to very large sizes and height.
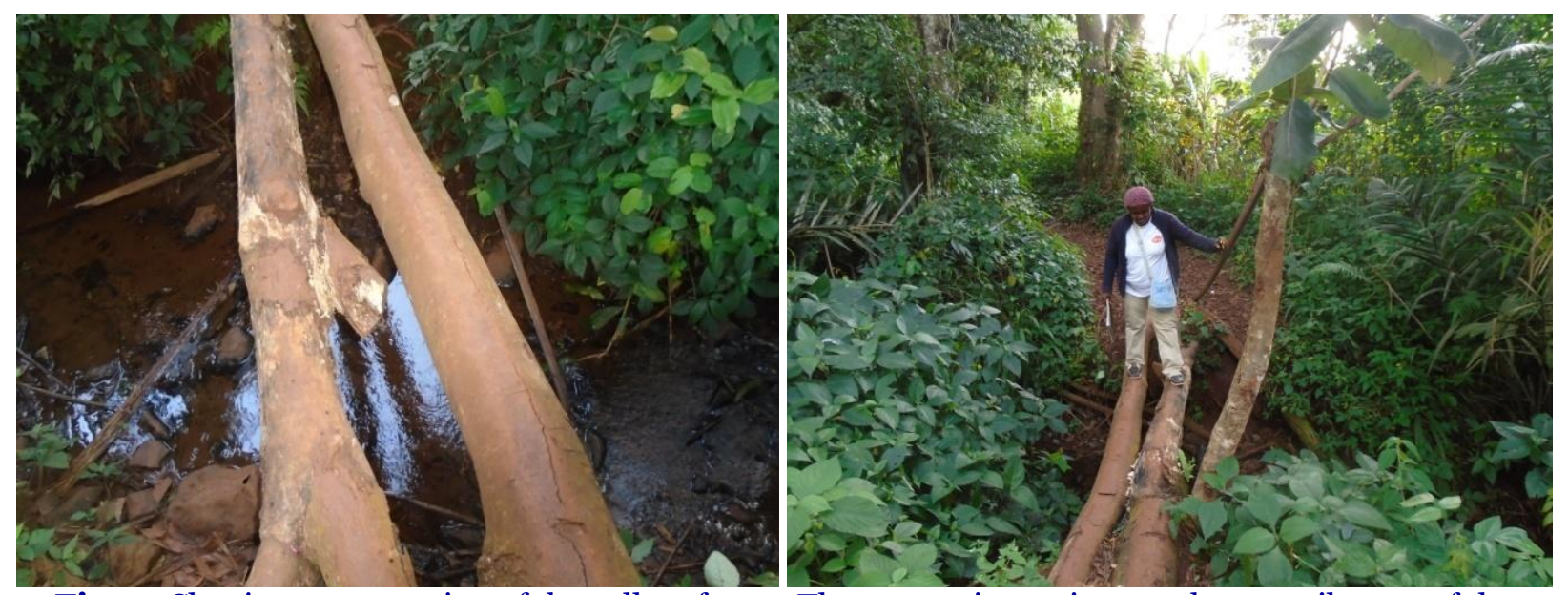

Fig. 3: Classic representation of the gallery forest. The canopy is contiguous above a tributary of the Lionlong River. The photography shows the fall of the tributary.

Of the 265 species harvested 255 have been identified (Table 1). The nomenclature follows Lebrun and Stork (1991-1997). The scientific name authors appear in the Table 1 . These species regroup themselves in 192 genera and 82 families. The richest families are the Leguminosae (Fabaceae, Caesalpiniaceae and Mimosaceae disconcerted) represented by 30 species, the Asteraceae (13), Euphorbiaceae (12), Moraceae (11), Meliaceae (10), Acanthaceae (9), and Rubiaceae (9) (Fig. 4). 


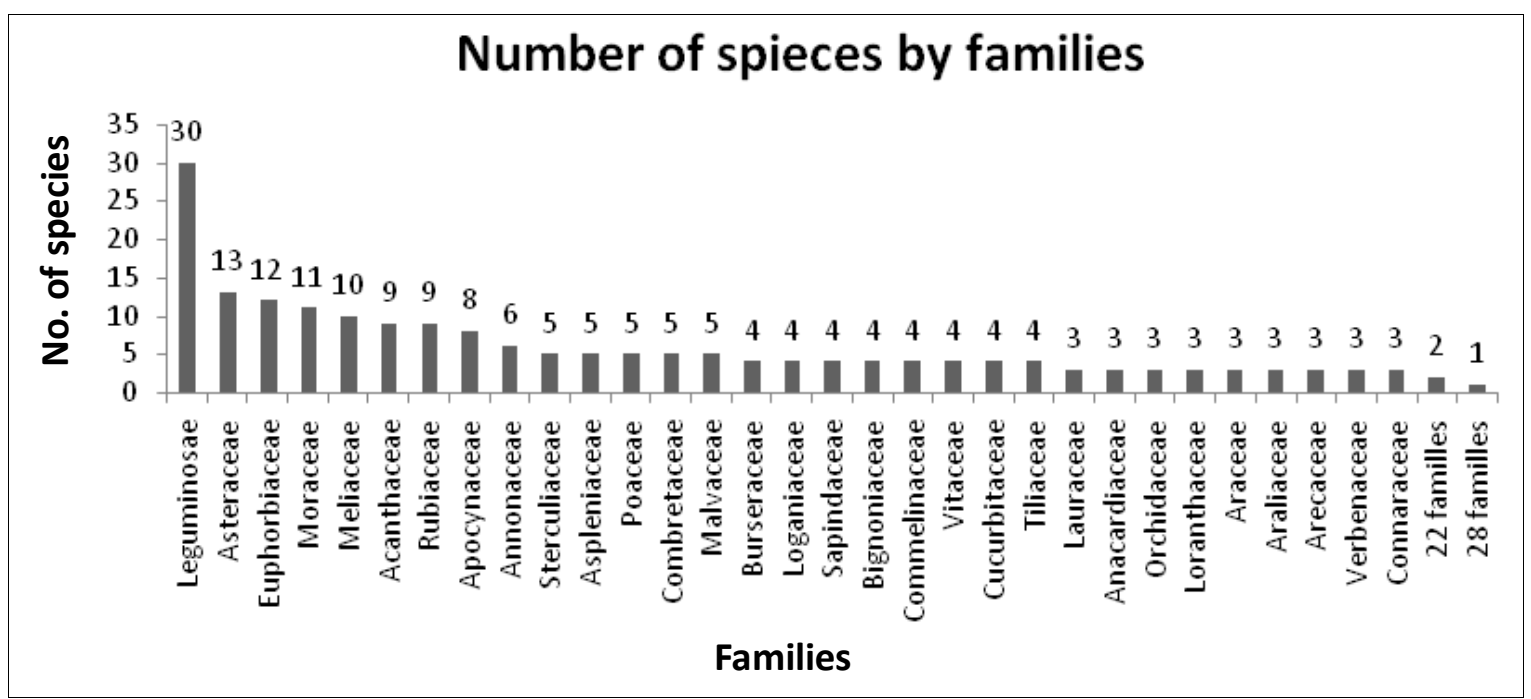

Fig. 4: Specific diversity of the families encountered in the floristic inventory of the Kouoghap gallery forest. The numbers of recorded species are indicated for each family.

The species in Kouoghap belong to 15 different biological types, and can be regrouped into 4 morphological types. There is dominance of the tree species (119, either 44.9\%) that occupy the first place in the forest by their biomass, followed by the herbaceous species (66, either 24.9\%). The proportion of the lianas (53 species, either 20\%) is moderate, and the under-shrub and subfrutescentes (27, either 10.1\%) are least represented.

\section{Vertical structure and physiognomy}

The plant formation is nearly represented by a pluri-stratum population of woody, reaching a height of 25-30 m. In the south side, the species as Syncepalum ceraciferum and Canarium schweinfurthii, rise above the forest and support climbing stems like Entada giga, Dalbergia hostilis, and Cissus petiolata. It is the stratum arborecent with Lovoa trichilioides, Entandrophragma utile and Pitadeniastrum africanum. The Table 1 presents the stratification of the Kouoghap forest. The shrubby stratum represents the most dominant stratum with $27.55 \%$ of the raw specter, followed by the herbaceous stratum with $\mathbf{2 1 . 5 1 \%}$. The epiphytes are the least represented with $3.4 \%$. The arborescent stratum reaches $45.55 \%$ for the weighted spectrum.

\section{Plant grouping individualization}

The data correspond to a raw matrix of 10 samplings and 265 plant species. On Fig. 5, the dendrogram of the hierarchical classification of the samplings reveals the heterogeneity (associations and appearance) within a same plant formation.

Three plant groupings have been noticed:

- the group of the sampling corresponding to the gallery forest (in the sense of the world): samplings R1, R2, R6, R7 and R9;

- the group of the samplings corresponding at the rainforest (in the sense of the world): samplings R3, R4S, R5S and R8 S;

- the sampling R10 corresponding to the various plant groupings. The fieldwork done in the lower limit of the forest edged by a coffee plantation (Coffea arabica, Rubiaceae) and the Lionlong River.

The partition from that matrix of 10 samplings and 265 species, according to the axes 1 and 2, individualized the 3 groups of the dendrogramme:

- the group of the sampligs executed on the high and peripheral part of the forest (R1 R2, R6, R7, R9);

- the group of the samplings done on the slopes of the forest ( $\left.\mathrm{R}_{3}, \mathrm{R}_{4}, \mathrm{R}_{5}, \mathrm{R} 8\right)$;

- The samplingwas done in the lower limit of the forest besides the coffee farms;

- The Fig. 6 illustrates the representation in the factorial plan 1 and 2 of the factorial analysis of the correspondences. 


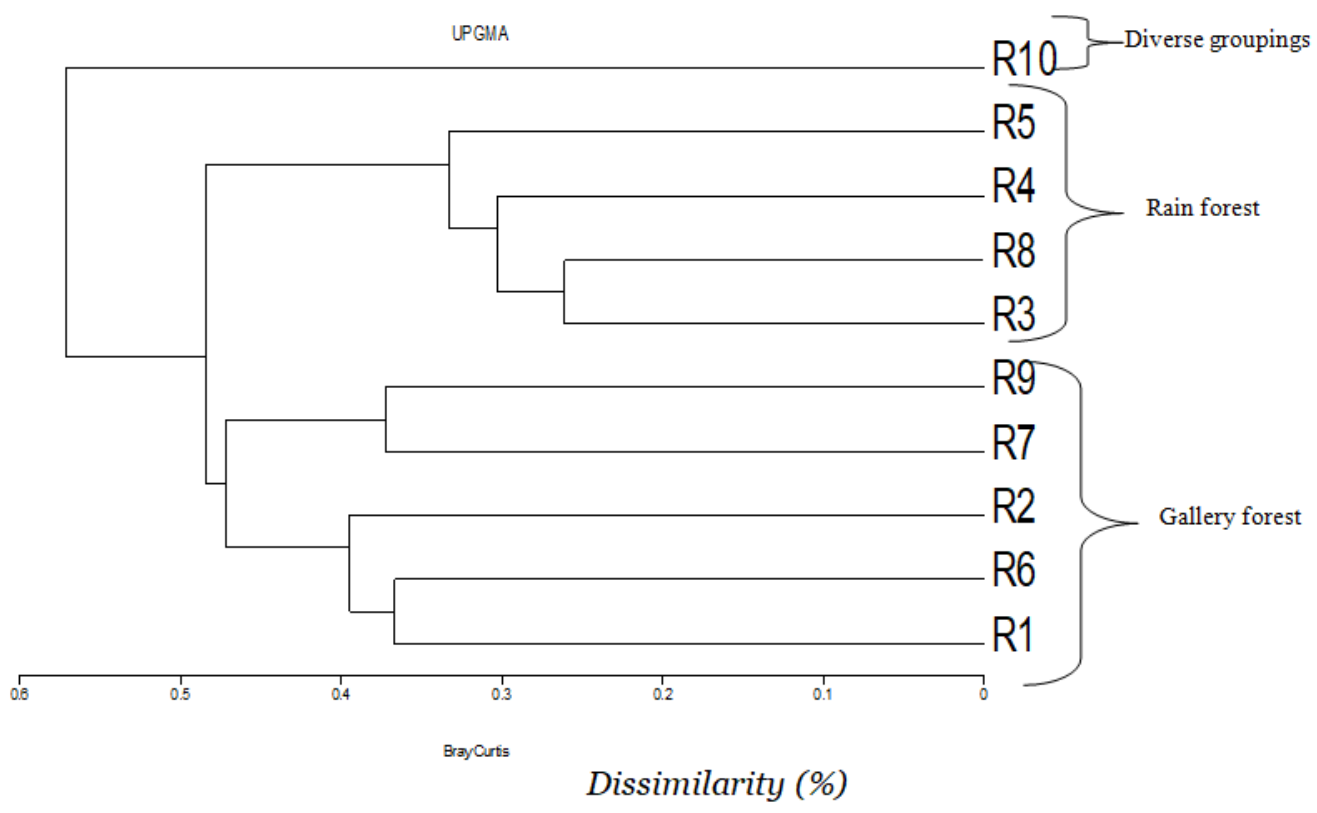

Fig. 5: Dendrogram of the plant formations of the sacral gallery Kouoghap forest (in the broad sense). V-gr: various plant groupings; G-f-sw: gallery forest in the stands of the world; R-f: rainforest.

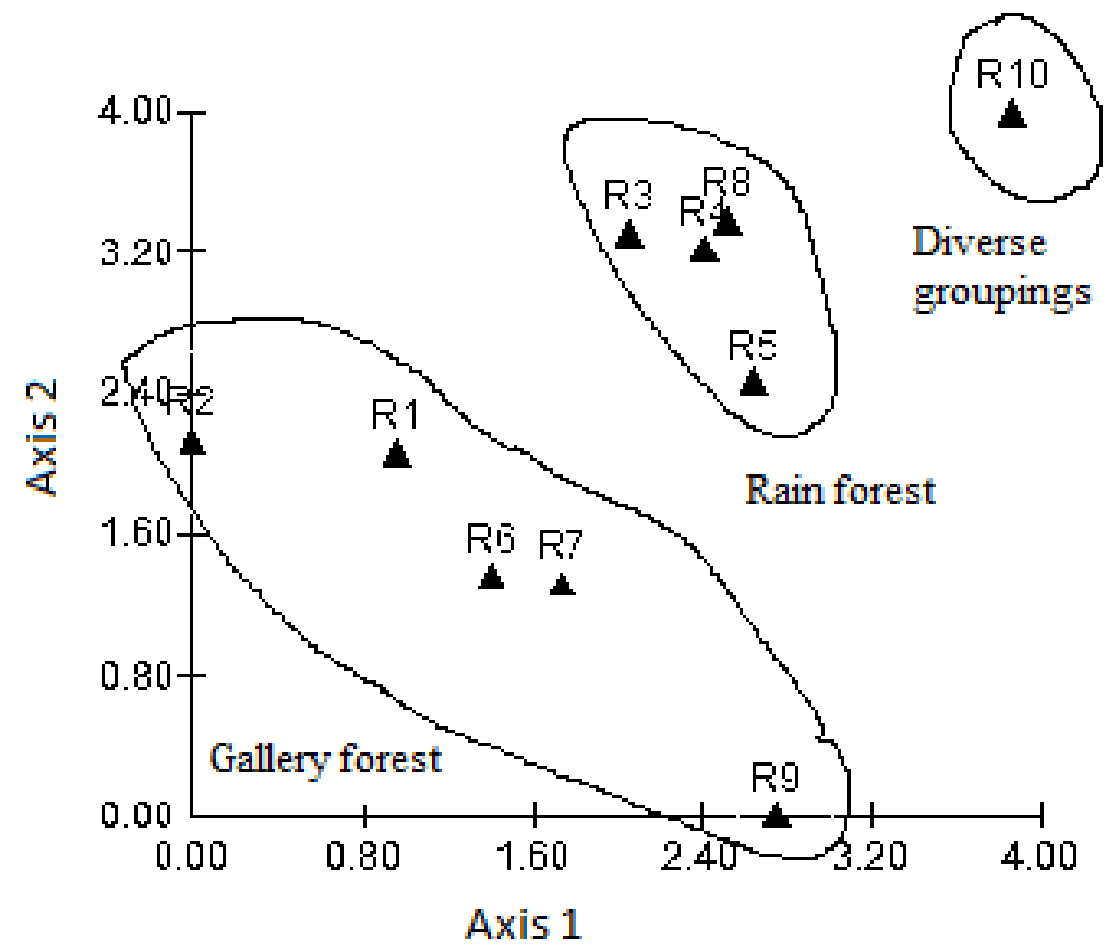

Fig. 6: Card of localization of the phytosociologic samplings; representation on the factorial plan 1 and 2 of the different groupings of the succession rainforest- gallery forest in the Kouoghap sylve.

The axis 1 symbolizes a hygometric pressure gradient in the same zone, even by the edaphic nature of the soil facing the depth of the water table (from the periphery of the drier forest, toward the river Lionlong, more humid place). The axis 2 represents the climatic phenomenon game in the neighborhood of the zone of instability of the 2 climatic regimes; equatorial climate with the 
humid wind or monsoon (Guinean zone) and the tropical climate with the dry wind or Harmattan (Soudanian zone).

\section{Feature of the different groups of samplings}

The Table 1 gives the structural characteristics of the forests of the succession rainforest-gallery forest in the Kouoghap sylve (Letouzey, 1968; Hill, 1994). The specific richness of these groupings varies from 145 to 157 species. The Shannon diversity index varies from 4.72 to 5.62 . The relative coverage of the groupings varies from 8 to $55 \%$.

Table 1. Structural features of the formations in succession in the Kouoghap sacral forest.

\begin{tabular}{|c|c|c|c|c|c|}
\hline Forest type & Localisation & Characteristic species & $\begin{array}{l}\text { Species } \\
\text { richness }\end{array}$ & $\begin{array}{l}\text { Shannon } \\
\text { diversity } \\
\text { index (H') }\end{array}$ & $\begin{array}{l}\text { Relative } \\
\text { coverage } \\
\text { average } \\
(\%)\end{array}$ \\
\hline Gallery forest & $\begin{array}{l}\text { Samplings done } \\
\text { from the high } \\
\text { slope toward the } \\
\text { river Lionlong }\end{array}$ & $\begin{array}{l}\text { Amphimas pterocarpoïdes, } \\
\text { Canarium schwenfurthii, } \\
\text { Dacryodes macrophylla, } \\
\text { Myrianthus arboreus, } \\
\text { Syncepalum ceraciferum. }\end{array}$ & 147 & $4 \cdot 74$ & 55 \\
\hline Rain forest & $\begin{array}{l}\text { Sampling done } \\
\text { on the slope of } \\
\text { the gallery forest }\end{array}$ & $\begin{array}{l}\text { Anonidium mannii, } \\
\text { Alchornea floribunda, } \\
\text { Carapa grandiflora, } \\
\text { Lovoa trichilioides, } \\
\text { Rauvolfia macrophylla, } \\
\text { Tricalysia macrophylla. }\end{array}$ & 145 & 4.72 & 37 \\
\hline $\begin{array}{l}\text { Various } \\
\text { groupings with } \\
\text { the transgressive } \\
\text { species of the } \\
\text { forests }\end{array}$ & $\begin{array}{l}\text { Sampling } \\
\text { adjoined the } \\
\text { field of coffee } \\
\text { culture before } \\
\text { the river } \\
\text { Lionlong }\end{array}$ & $\begin{array}{l}\text { Al bizia adianthifolia, } \\
\text { Canarium schweinfurthii, } \\
\text { Polyscias fulva, } \\
\text { Pychnanthus angolensis, } \\
\text { Markhamia tomentosa, } \\
\text { Trilepisium madagascariense. }\end{array}$ & 157 & 5.62 & 8 \\
\hline
\end{tabular}

\section{Syntaxonomic position}

The horizontal specific regrouping of 10 samplings (Table 1) permits to have sets of species corresponding appreciably to phytosociologic orders and classes, according to the zurichomonpellierain system, and assimilatedto ecosociological groups.

- A first group constituted of the gallery forest species along the temporary Lionlong River. This group corresponds to the order of the Pteygotetalia Lebrun and Gilbert 1954. It is in fact the plants of semi-deciduous dense forests in more watered environment that compensates the pluviometric deficit by their proximity to the river. These species belong to the alliance of the Khayo-Pterygotion Schmitz 1950 for the Soudano-Zambezian formations. Pteygotetalia presents some semi- deciduous species of the equatorial mesophile forests
(Piptadeniastro-Celtidetalia) (Letouzey, 1968; Letouzey, 1968; Hill, 1994); then the equatorial secondary forest species of the (MusangetoTerminalietea Lebrun and Gilbert 1954), with species such as: Synsepalum cerasiferum, Hylodendron gabunense, Guarea thompsonii, Amphimas pterocarpoïdes Lovoa trichilioides and Funtumia elastica. This grouping represents the association of Syncepalum ceraciferum.

- A second honestly ombrophile set (class of the Strombosio-Parinarietea Lebrun and Gilbert 1954) includes the species of the sempervirentes rainforests. This taxon regroups 3 orders: The FicalhoetoPodocarpetalia Lebrun and Gilbert 1954, the Gilbertiodendretalia dewevrei Lebrun and Gilbert 1954 and the Garcinietalia Noumi 1998. In this last taxon, one notes the presence of the species of an alliance: the Garcinion 
Noumi 1998 with Draceana arborea, Garcinia smeathmannii, Tricalysia macrophyllaas indicator species. This grouping represents the association to Tricalysia macrophylla.

- A third set regroups several other phytosociologic groupings: the class of the Mitragynetea Schmitz 1963 that regroups all hygropile edaphic forests; the order of the Oleo-Jasminetalia Lebrun and Gilbert 1954 of the sclerophyll forests with Canthium vulgare; Pittosporum mannii and Maytenus senegalensis that are pledged to him. Still in the Kouoghap sacral forest, one meets the characteristic species of the MusangoTerminalietea Lebrun and Gilbert 1954, of the secondary forests of low and middle altitudes ; the characteristic species of the Polyscietalia fulvae Lebrun and Glibert 1954 of regrew and secondary forests of mountain; the characteristic species of the Ruderalimanihotetea Hoff \& Brisse 1983 of ruderal groupings; the characteristic species of the
Hyparrhenietea Schmitz 1963 of the vegetations of the non steppe savanna in Soudano-Zambezian region.

\section{Ecological spectra of the species of the Kouoghap gallery forest (in the broad sense)}

\section{Biological type spectra}

The results of the analysis of the biological types of the forest (Table 6), are taken in the Table 2. The importance of the phanerophytes (76.98\%) for the raw spectrum is put in evidence. This group is followed of therophytes (8.3\%). Also the weighted specter is dominated by the phaneropytes that reaches $95.47 \%$ of the relative coverage. The two characteristic species: Tricalysia macrophylla and Syncepalum serasiferum represents $17.28 \%$ and $8.85 \%$ of the relative coverage of the association. The chamephytes and hemicryptophytes are least represented in terms of surface coverage.

Table 2. Biological type spectra.

\begin{tabular}{|c|c|c|c|c|c|}
\hline \multirow{2}{*}{ Biological types } & & \multicolumn{2}{|l|}{ Raw spectrum } & \multicolumn{2}{|c|}{ Weighted spectrum } \\
\hline & & No. of species & $\%$ & Coverage & $\%$ \\
\hline \multirow[t]{5}{*}{ Phanerophytes } & & 204 & 76.98 & 208.55 & 95.47 \\
\hline & Microphanerophytes (Mcph) & 65 & 24.53 & 56.05 & 25.66 \\
\hline & Phanerophyticlianas (Ph-L) & 52 & 19.62 & 21.85 & 10.00 \\
\hline & Mesophanerophytes (Msph) & 51 & 19.25 & $105 \cdot 55$ & 48.32 \\
\hline & Nanophanerophytes (Nnph) & 36 & 13.58 & 25.10 & 11.49 \\
\hline \multirow[t]{3}{*}{ Therophytes } & & 22 & 8.30 & 1.4 & 0,64 \\
\hline & Therophytes erected (T-erec) & 19 & 7.17 & 1.05 & 0.48 \\
\hline & Therophytic lianas (T-L) & 3 & 1.13 & 0.35 & 0.16 \\
\hline \multirow[t]{5}{*}{ Geophytes } & & 18 & 6.41 & 5.65 & 2.58 \\
\hline & Rhizome-geophytes (G-rhiz) & 11 & 4.15 & 4.85 & 2.22 \\
\hline & Root-budding geophytes (G-rad) & 4 & 1.51 & 0.55 & 0.25 \\
\hline & Bulbous geophytes (G-bulb) & 2 & 0.75 & 0.2 & 0.09 \\
\hline & $\begin{array}{l}\text { Rhizome geophytes (hemi-epyphites) } \\
\text { (G-rhiz-E) }\end{array}$ & 1 & 0.38 & 0.05 & 0.02 \\
\hline \multirow[t]{3}{*}{ Chamaephytes } & & 13 & 4.91 & 17.0 & 0.78 \\
\hline & Chamephytes erected (Ch-erec) & 9 & 3.40 & 1.35 & 0.62 \\
\hline & Chamephytes epiphytes (Ch-E) & 4 & 1.51 & 0.35 & 0.16 \\
\hline \multirow[t]{6}{*}{ Hemicryptophytes } & & 8 & 3.02 & 1.15 & 0.52 \\
\hline & Caespitose hemicryptophytes (H-caesp) & 4 & 1.51 & 0.35 & 0.16 \\
\hline & Hemicryptophytes epiphytes (H-E) & 2 & 0.75 & 0.4 & 0.18 \\
\hline & Hemicryptophytes creeping & 1 & 0.38 & 0.05 & 0.02 \\
\hline & Hemicryptophytes reptant (H-rept) & 1 & 0.38 & 0.35 & 0.16 \\
\hline & Total & 265 & 100 & 218.45 & 100 \\
\hline
\end{tabular}




\section{Phytogeographic type spectra}

The detailed exam of type of the geographical distribution of the specific whole (Table 6) gave the groups and values encoded consigned in the Table 3. The Guineo-Congolese species group comes first for the raw specter $(52.08 \%)$ of the specific whole and for the weighted specter $(63.28 \%$ of the coverage). The following findings could be cleared:
- the floristic font of the formation is dominated by the Guineo-Congolese species.

- this type of plant formation is spilled in the Guinean zone in which meets the main species of the association.

- the extensively widespread species group poorly represented ( $15.85 \%$ of the raw specter), with only $7.82 \%$ of land coverage.

Table 3. Phytogeographic type spectra.

\begin{tabular}{lllll}
\hline \multirow{2}{*}{ Phytogeographical type } & Raw spectrum & \multicolumn{2}{l}{ Weighted spectrum } \\
\cline { 2 - 5 } & No. of species & \% & Coverage & \% \\
\hline Guineo-congolese species & 137 & 51.71 & 118.9 & 54.43 \\
Omni- or subomni-guineo-congolese (G) & 70.00 & 26.42 & 46.80 & 21.42 \\
Centro-guineo-congolese (Cg) & 66.00 & 24.91 & 71.95 & 32.94 \\
Camerounian (Ca) & 1.00 & 0.38 & 0.15 & 0.07 \\
Widely spread species & 44 & 16.6 & 39.85 & 18.26 \\
Pantropical (Pan) & 14.00 & 5.28 & 12.50 & 5.72 \\
Afro-american (Aam) & 9.00 & 3.40 & 1.00 & 0.46 \\
Afro-malagasy (Am) & 9.00 & 3.40 & 1.35 & 0.62 \\
Afromountaneous (Amo) & 5.00 & 1.89 & 0.45 & 0.21 \\
Paleotropical (Pal) & 3.00 & 1013 & 1.65 & 0.76 \\
Pluri-regional african (Pra) & 2.00 & 0.75 & 22.80 & 10.44 \\
Afro-asian (Aas) & 2.00 & 0.75 & 0.10 & 0.05 \\
Species ofliaison & 74 & 27.92 & 57.8 & 26.46 \\
Afro-tropical (At) & 38.00 & 14.34 & 24.50 & 11.22 \\
Guineo-sudano-zambezian (G-Sz) & 36.00 & 13.58 & 33.30 & 15.24 \\
Indeterminated species & 10.00 & 3.77 & 1.90 & 0.87 \\
Total & 265 & 100 & 218.45 & 100 \\
\hline
\end{tabular}

\section{Spectra of diaspore types}

The Table 4 summarizes the results of the analysis of the types of diaspores as presented in the Table 6. The importance of the sarcochores for the raw specter (52.45\%) and the weighted specter
(71.30\%) are put in evidence. The pterochores, is in the $4^{\text {th }}$ position in the raw specter, and $2^{\text {nd }}$ in the weighted specter with $11.35 \%$. The desmochores are the less represented with only $2.26 \%$ in the raw specter. The majority of the species is susceptible to be scattered by the animals.

Table 4. Diaspore type spectra.

\begin{tabular}{lllll}
\hline \multirow{2}{*}{ Diaspore type } & Raw spectrum & \multicolumn{3}{c}{ Weighted spectrum } \\
\cline { 2 - 5 } & No. of species & \% & Coverage & \% \\
\hline Sarcochore (Sarco) & 139 & 52.45 & 155.75 & 71.30 \\
Ballochore (Ballo) & 36 & 13.58 & 19.1 & 8.74 \\
Sclerochore (Sclero) & 30 & 11.32 & 3.6 & 1.65 \\
Pterochore (Ptero) & 27 & 10.19 & 24.8 & 11.35 \\
Pogochore (Pogo) & 18 & 6.79 & 12.5 & 5.72 \\
Barochore (Baro) & 9 & 3.40 & 2.4 & 1.10 \\
Desmochore (Desmo) & 6 & 2.26 & 0.3 & 0.14 \\
Total & 265 & 100 & 218.45 & 100 \\
\hline
\end{tabular}




\section{Ecosociological units}

The results of the analysis of the ecosociological unit types of the species of the plant formation are presented to the Table 5. The groupings of the sempervirent ombrophile forests of the Table 6 show a total of 94 species (35.48\%). They are followed by the groupings of the mesophile semicaducifolious forests that present 53 species that is $20.37 \%$ of the set of the species. In the weighted spectrum, the species of ombrophile and secondary forests reach coverage of $73.47 \%$ of the total average coverage of the study area. In this context, the set of the species of the Garcinietalia to which belongs Tricalysia macrophylla reach a relative coverage of $23.27 \%$. They largely determine the physiognomy of the Kouoghap sylva. The forest (senso-stricto) totals 17 species (6.42\%), reaching a relative coverage of $13.48 \%$ that places it in the $3^{\text {rd }}$ position of the relative coverage. Syncepalum cerasiferum belongs to this set described as plant association, whose species determine largely the evolutionary dynamic of the Kouoghap sylva.

Table 5. Ecosociological groups spectra.

\begin{tabular}{|c|c|c|c|c|c|}
\hline \multirow{2}{*}{$\begin{array}{l}\text { Phytosociologic } \\
\text { statute }\end{array}$} & \multirow{2}{*}{ Classes and Ordres } & \multicolumn{2}{|l|}{ Raw spectrum } & \multicolumn{2}{|c|}{ Weighed spectrum } \\
\hline & & No. of species & $\%$ & Coverage & $\%$ \\
\hline \multirow{5}{*}{\multicolumn{2}{|c|}{$\begin{array}{l}\text { Species of the sempervirente ombrophile forests } \\
\qquad \begin{array}{l}\text { Strombosio-Parinarietea (Strom) } \\
\text { Gilbertiodendretalia dewevrei (Gilb) } \\
\text { Ficalhoeto-Podocarpetalia (Fic) } \\
\text { Garcinietalia (Gar) }\end{array}\end{array}$}} & 94 & 35.48 & 90.65 & 41.5 \\
\hline & & 24 & 9.06 & 16.65 & 7.62 \\
\hline & & 32 & 12.08 & 16.05 & 7.35 \\
\hline & & 10 & 3.77 & 6.9 & 3.16 \\
\hline & & 28 & 10.57 & 51.05 & 23.37 \\
\hline \multirow{3}{*}{ Secondary forests } & & 50 & 18.86 & 69.85 & 31.97 \\
\hline & Musango-Terminalietea (Mus) & 44 & 16.6 & 58.55 & 26.80 \\
\hline & Polyscietalia fulvae (Polys) & 6 & 2.26 & 11.3 & 5.17 \\
\hline \multicolumn{2}{|c|}{ Species of edaphic forests bound to the hydromorphe soils } & 14 & 5.29 & 8.75 & 2.56 \\
\hline \multirow{2}{*}{\multicolumn{2}{|c|}{$\begin{array}{l}\text { Mitragynetea (Mytra) } \\
\text { Lanneo-Pseudospondietalia (Lan) }\end{array}$}} & 13 & 4.91 & 5.25 & 2.40 \\
\hline & & 1 & 0.38 & 3.5 & 0.16 \\
\hline \multirow{3}{*}{\multicolumn{2}{|c|}{$\begin{array}{l}\text { Species of mesophile semi - caducifolious forests } \\
\text { Piptadeniastro-Celtidetalia (Pip) } \\
\text { Oleo-Jasminetalia (Oleo) }\end{array}$}} & 53 & 20.37 & 20.3 & 9.29 \\
\hline & & 43 & 16.6 & 19.35 & 8.86 \\
\hline & & 10 & 3.77 & 0.95 & 0.43 \\
\hline \multicolumn{2}{|c|}{ Species of gallery forets } & 17 & 6.42 & 29.45 & 13.48 \\
\hline & Pterygotetalia (Ptery) & 17 & 6.42 & 29.45 & 13.48 \\
\hline \multicolumn{2}{|c|}{ Cultural and postcultural vegetations } & 19 & 7.17 & 1.25 & 0.57 \\
\hline & Soncho-Bidentetea pilosi (Sonc) & 19 & 7.17 & 1.25 & 0.57 \\
\hline \multicolumn{2}{|c|}{ Vegetations of the non steppic savannas in the region } & 16 & 6.04 & 1.55 & 0.71 \\
\hline \multicolumn{2}{|c|}{$\begin{array}{l}\text { Hyparrhenietea (Hyppar) } \\
\text { Unsettled surroundino verations }\end{array}$} & 16 & 6.04 & 1.55 & 0.71 \\
\hline \multicolumn{2}{|c|}{ Unsettled surrounding vegetations } & 2 & 0.75 & 0.1 & 0.05 \\
\hline & Ruderali-Manihotetea (Rud) & 2 & 0.75 & 0.1 & 0.05 \\
\hline \multirow{2}{*}{\multicolumn{2}{|c|}{$\begin{array}{c}\text { Vegetations of the large valleys funds and the lake sides } \\
\text { Phragmitetea (Phrag) }\end{array}$}} & 1 & 0.38 & 0.05 & 0.02 \\
\hline & & 1 & 0.38 & 0.05 & 0.02 \\
\hline \multicolumn{2}{|l|}{ Total } & 265 & 100 & 218.45 & 100 \\
\hline
\end{tabular}

Study of the two forests in succession: gallery forest (in the sense of the world) of Syncepalum cerasiferum and forest confer (FC) sempervirent of Tricalysia macrophylla

\section{Definition}

The elements belonging to a type of forests maybe more or less sempervirent (forest $\mathrm{CF}$ sempervirent), developed during one more humid previous period, can be included currently in regrew forest that evolve toward the semi deciduous forest (Koechlin and Trochain, 1955). The sempervirent forest is represented by the association of Tricalysia macrophylla; the semideciduous forest is represented by the association of Synsepalum cerasiferum. The topographic localization of the old elements on the flanks of valleys decorated to bring some arguments in favour of this thesis. The northern limit of the semi-deciduous forest of Sterculiaceae and Ulmaceae gives out long appendixes named 
"gallery foresry". There, the forest population establishes itself of a more or less continuous and extended manner, on the flanks of the valleys (Letouzey, 1968.) The sacral Kouoghap submountaneous forests, is a representative of the gallery forests of the northern peripheral domain of the Guineo-Congolese region.

\section{Gallery forest of Syncepalum cerasiferum [Syn. Afrosersalisia cerasifera (Welw.) Aubr.]}

\section{Definition}

The association of Syncepalum ceraciferum is a vegetation of high cluster, in succession in the sacral forest of the Batoufam village, situated on the south side of the valley between the Famla and Fieutchip quarters, in a fragment of gallery forest. It is surrounded by farming lands and Terminalia glaucescens, signifying the relics of the savannahs.

\section{Phytosociologic study}

Floristic composition: The floristic composition of the grouping forming the association to Syncepalum cerasiforum is given by 5 samplings (Table 1). The total number of species varies between 53 and 69 with an average of 62 species by sampling. The sampling type is represented by $\mathrm{R} 1$ and the characteristic of the association is Syncepalum cerasiferum.

Order of Pterygotetalia: From a physiognomic view point, Kouoghap is a forest grouping of high cluster that occupies the south flank of the valley drained by the Lionlong River. The formation benefits from a favorable macroclimate due to the constriction of the sides of this valley. These particular mesologic conditions make it as a vallicole forest. Lebrun and Gilbert (1954) defined the order of the Pterygotetalia Lebrun and Gilbert 1954, constituted of the species of dense semideciduous forest in more watered environment that compensates the pluviometric deficit by their proximity of the rivers. In several northern valleys in Cameroon, the presence of characteristic species of the order was raised (Letouzey, 1968): Pterygota bequaerti and Pterygota macrocarpa. We affiliate the association of Syncepalum cerasifolium to this phytosociologic order. A characteristic of the alliance of the Khayo-Pterygotion Schmitz 1950
(Khaya grandifolia), also reported (Letouzey, 1968), permit to affiliate the association of Syncepalum cerasiferum to this syntaxon. One rises in the association many elements descended of the various types of Guinean forests: caducifolious species as Canarium schweinfurthii and Funtumia elastica; secondary forest species as Albizia adianthifolia, Pychnanthus angolensis and Hylodendron gabunense; species of the sempervirent forests as Strombosia grandifolia, Guarea thompsonii. These species become quickly familiar to this northern zone.

\section{Syncepalum cerasiferum (Sapotaceae) -} Meso-phanerophyte, sarcochore: Species of the mountains and the forestry galleries of the northern peripheral domain of the guineocongolian region, present from the of Fouta-Djalon mountanes in Guinea to the Republic Centrafrican, then in the south Hémispher in the Equatorial Guinea and Angola. It is signalled in the highlands of the West Cameroon and in the Adamaoua. It is a big tree, reaching $30 \mathrm{~m}$ of height and $70 \mathrm{~cm}$ of diameter. Stembark section pinkish exuding a white latex, gluing. The stem is cylindrical and right, without buttress to the basis. The deciduous leaves are in terminal tufts (Aubréville, 1964). Its coverage reaches up to $40.9 \%$.

\section{Ecological spectra of the species of the gallery forest of Syncepalum cerasiferum}

The raw spectrum of the biological types of species of the forest gallery (sensus stricto) shows the predominance of the mesophanerophytes and microphanerophytes. The phanerophytes erected (trees and bushes) represent $61.9 \%$ of the total of the species, while the phanerophytic lianas $25.17 \%$. The raw spectrum of the dissemination types of the diaspores of the species of the sempervirent forest shows the predominance of the sarcochories that represents $62.59 \%$ of the total of the species. The barochories and the pogonochories represent $4.76 \%$ respectively. The raw spectrum of the ecosociological groups of the species shows the predominance of the species of the mesophiles forests (Pip) and of the secondary forests (Mus). When one considers only the characteristic species of the gallery forest (strict sense), the species of the order of the Pterygotetelia Lebrun and Gilbert 1954 come in $5^{\text {th }}$ position for the raw specter (9.52\%) of the ecosociological types (Table 1 ). 


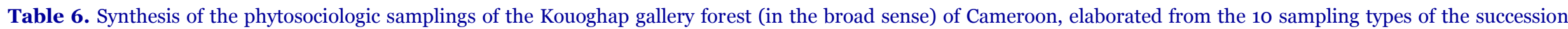
forest CF sempervirent- gallery forest (in the sens of the world).

\begin{tabular}{|c|c|c|c|c|c|c|c|c|c|c|c|c|c|c|c|c|c|c|}
\hline Families & BT & PT & DDT & EG & species & Strat & $\mathbf{R 1}$ & R2 & $\mathbf{R 3}$ & $\mathbf{R 4}$ & $\mathbf{R} \mathbf{5}$ & R6 & $\mathbf{R}_{7}$ & $\mathbf{R 8}$ & R9 & R10 & $\mathbf{P}$ & $\mathbf{F}$ \\
\hline \multicolumn{19}{|c|}{ Ficalhoeto-Podocarpetalia, Lebrun and Gilbert 1954} \\
\hline Leguminosae & Msph & G-Sz & Baro & Fical & Albizia gummifera (J. F. Gmel) C. A. Sm.var. gummifera & $\mathrm{T}$ & 1 & + & + & + & + & + & + & + & & & 8 & 80 \\
\hline Meliaceae & Msph & G & Sarco & Fical & Carapa grandiflora Sprague & $\mathrm{T}$ & 2 & 1 & 1 & & 2 & 1 & 2 & + & + & & 8 & 80 \\
\hline Rubiaceae & Nnph & Ind & Sarco & Fical & Cephaelis sp. & $\mathrm{s}$ & + & & & + & & & & + & + & + & 5 & 50 \\
\hline Myrsinaceae & $\mathrm{PhL}$ & $\mathrm{Cg}$ & Sarco & Fical & Ardisia kivuensis Taton & 1 & & & & & & & & & + & & 1 & 10 \\
\hline Melianthaceae & Msph & $\mathrm{Cg}$ & Ballo & Fical & Bersama abyssinica Fres. & $\mathrm{s}$ & & & + & & + & & & & + & & 3 & 30 \\
\hline Leguminosae & $\mathrm{PhL}$ & $\mathrm{Cg}$ & Ballo & Fical & Milletia pilosa Hutch. \& Daziel & 1 & & & & & & & & & + & & 1 & 10 \\
\hline Rosaceae & Msph & Pan & Sarco & Fical & Prunus Africana (Hook.f.) Kalkman & $\mathrm{T}$ & + & & & & & & & & & & 1 & 10 \\
\hline Araliaceae & $\mathrm{PhL}$ & G-Sz & Sarco & Fical & Schefflera abyssinica (Hochst. Ex A. Rich.) Harms & 1 & + & & & & & & & & & + & 2 & 20 \\
\hline Araliaceae & $\mathrm{PhL}$ & G-Sz & Sarco & Fical & Schefflera barteri (Seem.) Harms & 1 & & & & & & & & & & + & 1 & 10 \\
\hline Asteraceae & Mcph & G & Sarco & Fical & Vernonia blumeiodes Hook. f. & $\mathrm{s}$ & & & & & & & & & & + & 1 & 10 \\
\hline \multicolumn{19}{|c|}{ Garcinietalia Noumi 1998} \\
\hline Orchidaceae & Ch-E & G & Sclero & Gar & Ancystrorhynchus capitalus (Lindl,) Summerh, & $\mathrm{h}$ & & & + & & & & + & & & & 2 & 20 \\
\hline Acanthaceae & Ch -erec & G & Sclero & Gar & Brillantaisia bauchiensis Hutch. \& Dalz. & $\mathrm{h}$ & & & & & & & & & & + & 1 & 10 \\
\hline Acanthaceae & Ch-erec & At & Sclero & Gar & Brillantaisia vogeliana (Nees) Benth, & $\mathrm{h}$ & & & & & + & & & & & & 1 & 10 \\
\hline Rutaceae & Mcph & $\mathrm{Am}$ & Sarco & Gar & Clausena anisata (Wills) Hook.f.ex Benth. & us & & & & & & & & & + & + & 2 & 20 \\
\hline Sterculiaceae & Msph & Aam & Sarco & Gar & Cola verticillata (Thonn) Stapf ex A. Chev. & $\mathrm{s}$ & & + & + & & & & & + & & & 3 & 30 \\
\hline Asteraceae & T-erec & G & Pogo & Gar & Crassocephalum mannii (Hook. F.) L. Redh. & $\mathrm{h}$ & & & & & & & & & & + & 1 & 10 \\
\hline Asteraceae & T-erec & G & Pogo & Gar & Crassocephalum rubens (Juss. ex. Jacq.) S. Moore & $\mathrm{h}$ & & & & & & & & & & + & 1 & 10 \\
\hline Rubiaceae & Mcph & $\mathrm{Cg}$ & Sarco & Gar & Tricalysia macrophylla K. Schum. & $\mathrm{T}$ & 4 & 3 & 3 & 3 & 2 & 3 & 3 & 3 & 3 & 3 & 10 & 100 \\
\hline Clusiaceae & Mcph & At & Sarco & Gar & Garcinia smeathmannii Oliv. & $\mathrm{s}$ & + & & & 1 & 1 & 3 & 2 & + & 2 & & 7 & 70 \\
\hline Dracaenaceae & Msph & $\mathrm{Cg}$ & Sarco & Gar & Draceana arborea (Willd.) Link. & $\mathrm{T}$ & 2 & 2 & + & & + & & + & + & + & & 7 & 70 \\
\hline Moraceae & Mcph & $\mathrm{Cg}$ & Sarco & Gar & Ficus jansii Boutique & $\mathrm{s}$ & & & + & & & & + & + & & & 3 & 30 \\
\hline Rubiaceae & Mcph & $\mathrm{Cg}$ & Sarco & Gar & Gaertnea paniculata Benth. & $\mathrm{s}$ & & & + & + & & & & & + & + & 4 & 40 \\
\hline Clusiaceae & Mcph & G & Sarco & Gar & Garcinia polyantha Oliv. & $\mathrm{T}$ & & & & + & & + & & & & & 2 & 20 \\
\hline Rosaceae & $\mathrm{PhL}$ & G-Sz & Sarco & Gar & Rubus pinnatus Willd. & 1 & & & + & & + & & + & + & & + & 5 & 50 \\
\hline Apiaceae & T-erec & Amo & Ptero & Gar & Heteromorpha abyssinica (R, Br,) Hochst. & $\mathrm{h}$ & & & & & & & & + & & + & 2 & 20 \\
\hline Acanthaceae & Ch-erec & At & Ballo & Gar & Hypoetes aristata (Vahl) Saland.ex. Roem. \& Schul. & $\mathrm{h}$ & & & & & & & & & & + & 1 & 10 \\
\hline Crassulaceae & Ch-erec & Pan & Sclero & Gar & Kalanchoe crenata (And.) Haw. & $\mathrm{h}$ & & & & & & & & & & + & 1 & 10 \\
\hline Malvaceae & Nnph & G-Sz & Ballo & Gar & Kosteletzkya grantii (Mast.) Garcke & us & & & & & & & & & & + & 1 & 10 \\
\hline Leguminosae & Nnph & G & Sarco & Gar & Kotschya speciosa (Hutch.) Hepper & us & & & & & & & & & & + & 1 & 10 \\
\hline Asteraceae & T-erec & $\mathrm{G}$ & Pogo & Gar & Microglassa angolensis Oliv. \& Hiern & $\mathrm{h}$ & & & & & & & & & & + & 1 & 10 \\
\hline Boraginaceae & T-erec & Amo & Desmo & Gar & Myosotis scorpioidesL. & $\mathrm{h}$ & & & & & & & & & & + & 1 & 10 \\
\hline Opiliaceae & T-erec & G-Sz & Sarco & Gar & Opilia celtidifolia (Guill. \& Perr.) Engl.ex Walp. & us & & & & & & & & & & + & 1 & 10 \\
\hline Pittosporaceae & Mcph & G-Sz & Ballo & Gar & Pittosporum mannii Hook.f. & us & & & & + & & & & + & & + & 3 & 30 \\
\hline Pteridaceae & G-rhiz & G & Sclero & Gar & Pteris togoensis Hier. & $\mathrm{h}$ & & & & + & & + & & & & + & 3 & 30 \\
\hline Arecaceae & Mcph & $\mathrm{G}$ & Sarco & Gar & Raphia farinifera (Gaertn.) Hyl. & $\mathrm{s}$ & & + & + & & & & & & & & 2 & 20 \\
\hline Ulmaceae & Mcph & At & Sarco & Gar & Trema orientalis (L.) Blume & $\mathrm{s}$ & & & & & & & & & & + & 1 & 10 \\
\hline Annonaceae & Mcph & $\mathrm{Cg}$ & Ballo & Gar & Xylopia parviflora (A. Rich.) Benth. & $\mathrm{s}$ & & & 1 & & & & & & & + & 2 & 20 \\
\hline Annonaceae & Mcph & $\mathrm{Cg}$ & Sarco & Gar & Xylopia rubescens Oliv. & $\mathrm{T}$ & & & + & & + & & & & & & 2 & 20 \\
\hline
\end{tabular}

J. Makemteu and E. Noumi (2020) / Characterization of plant groups and description of plant succession in the sacred Kouoghap forest of the Batoufam village, West 


\begin{tabular}{|c|c|c|c|c|c|c|c|c|c|c|c|c|c|c|c|c|c|c|}
\hline Families & BT & PT & DDT & EG & species & Strat & R1 & R2 & $\mathbf{R 3}$ & $\mathbf{R 4}$ & $\mathbf{R}_{\mathbf{5}}$ & R6 & $\mathbf{R} 7$ & $\mathbf{R 8}$ & R9 & R10 & $\mathbf{P}$ & $\mathbf{F}$ \\
\hline \multicolumn{19}{|c|}{ Gilbertiodendretaliadewevrei, Lebrun and Gilbert 1954} \\
\hline Lauraceae & Mcph & $\mathrm{Ca}$ & Sarco & Gilb & Beilschmiedia grandifolia Rob.\& Wilcz & $\mathrm{s}$ & & & & & & & + & & + & + & 3 & 30 \\
\hline Simaroubaceae & Nnph & $\mathrm{Cg}$ & Sarco & Gilb & Brucea guineensis G.Don & us & & & & & & & & & & + & 1 & 10 \\
\hline Vitaceae & PhL & At & Sarco & Gilb & Cissus petiolata Hook. f. & 1 & & + & + & + & & & & + & + & & 5 & 50 \\
\hline Ranunculaceae & PhL & At & Pogo & Gilb & Clematis grandiflora DC. & 1 & & & & & & & + & & & + & 2 & 20 \\
\hline Cucurbitaceae & $\mathrm{PhL}$ & Aam & Sarco & Gilb & Cyclanthera brachystachya (Ser,) Cogn. & 1 & & & + & + & & & & & & + & 3 & 30 \\
\hline Sapindaceae & Mcph & $\mathrm{Cg}$ & Sarco & Gilb & Deinbollia maxima Gilg ex Radlk, & $\mathrm{s}$ & & & & & & & & & & + & 1 & 10 \\
\hline Euphorbiaceae & Mcph & $\mathrm{Cg}$ & Sarco & Gilb & Drypetes molunduana Pax \& K. Hoffm. & $\mathrm{s}$ & & & & & & & + & & & & 1 & 10 \\
\hline Arecaceae & $\mathrm{PhL}$ & $\mathrm{Cg}$ & Sarco & Gilb & Eremospatha wendlandiana Dammer ex Becc. & 1 & & + & & & & & & & & & 1 & 10 \\
\hline Tiliaceae & Nnph & $\mathrm{Am}$ & Baro & Gilb & Glyphaea brevis (Spreng.) Monachino & us & & & & & & & & & + & + & 2 & 20 \\
\hline Tiliaceae & Msph & G & Sarco & Gilb & Grewia coriacea Mast. & $\mathrm{T}$ & & & + & & & + & & & & & 2 & 20 \\
\hline Meliaceae & Mcph & G & Sarco & Gilb & Guarea glomerulata Harms & $\mathrm{T}$ & + & & + & & + & & & & & & 3 & 30 \\
\hline Orchidaceae & G-bulb & $\mathrm{G}$ & Sclero & Gilb & Habenaria gabonensis Rchb.f. & $\mathrm{h}$ & & & + & & & & & + & & & 2 & 20 \\
\hline Cucurbitaceae & PhL & G-Sz & Sarco & Gilb & Kedrostis hirtella (Naud.) Cogn. & 1 & & & & & & & & & & + & 1 & 10 \\
\hline Sterculiaceae & Nnph & At & Sarco & Gilb & Octolepis casearia Oliv. & $\mathrm{s}$ & + & & & & & & & & & & 1 & 10 \\
\hline Leguminosae & Msph & $\mathrm{Cg}$ & Baro & Gilb & Pachyelasma tessmannii (Harms) Harms & $\mathrm{s}$ & & & & + & + & & & + & & & 3 & 30 \\
\hline Aristolochiaceae & PhL & $\mathrm{Cg}$ & Sarco & Gilb & Pararistolochia mannii Hook.f. & 1 & & & + & & & & + & & & + & 3 & 30 \\
\hline Passifloraceae & PhL & Aam & Sarco & Gilb & Passiflora edulis Sims & 1 & & & & & & & & & & + & 1 & 10 \\
\hline Apocynaceae & PhL & At & Pogo & Gilb & Pergularia daemia (Forsk.) Chiov. & $\mathrm{h}$ & & & & & & & & & & + & 1 & 10 \\
\hline Loranthaceae & Nnph & $\mathrm{Cg}$ & Sarco & Gilb & Phragmanthera capitata (Spreng.) S. Balle & ep & & & & & & & & & & + & 1 & 10 \\
\hline Loranthaceae & Nnph & $\mathrm{Cg}$ & Sarco & Gilb & Phragmanthera incana (Schum.) Balle & ep & & & + & + & & & & + & & + & 4 & 40 \\
\hline Loranthaceae & Mcph & $\mathrm{Cg}$ & Sarco & Gilb & Phragmanthera kamerunensis (Engl.) Balle & ep & & & + & + & & & & & & & 2 & 20 \\
\hline Solanaceae & T-erec & G & Sarco & Gilb & Physalis peruviana $\mathrm{L}$. & $\mathrm{h}$ & & & & & & & & & & + & 1 & 10 \\
\hline Rubiaceae & Nnph & Ind & Sarco & Gilb & Psychotria sp. & us & + & & + & & + & + & + & + & & & 6 & 60 \\
\hline Rubiaceae & Nnph & Pan & Sarco & Gilb & Psychotria vogeliana Benth. & us & 2 & 3 & + & & + & 3 & 2 & + & & & 7 & 70 \\
\hline Icacinaceae & $\mathrm{PhL}$ & G-Sz & Sarco & Gilb & Raphiostylis beninensis (Hook.f.) Planch.ex. Benth. & 1 & & & + & + & + & & & + & 1 & + & 6 & 60 \\
\hline Acanthaceae & PhL & Ind & Pogo & Gilb & Rhinacanthus sp. & 1 & + & 1 & & & & + & + & & + & + & 6 & 60 \\
\hline Smilacaceae & PhL & At & Ptero & Gilb & Smilax kraussiana Meissn. & 1 & 1 & + & + & + & & + & & + & + & + & 8 & 80 \\
\hline Menispermaceae & PhL & $\mathrm{Cg}$ & Sarco & Gilb & Stephania dinklagei (Engl.) Diels & 1 & + & & & & + & & + & + & + & + & 6 & 60 \\
\hline Acanthaceae & Nnph & $\mathrm{Cg}$ & Ballo & Gilb & Thomandersia laurifolia (T. Anders.ex. Benth.) Baill & us & & + & & + & + & & & + & & & 4 & 40 \\
\hline Meliaceae & Mcph & Aam & Sarco & Gilb & Trichilia tessmannii Harms & $\mathrm{s}$ & & & & & & & & + & & & 1 & 10 \\
\hline Meliaceae & Mcph & $\mathrm{G}$ & Sarco & Gilb & Turraeanthus africanus (Welw.ex DC.) Pellegr. & $\mathrm{s}$ & & & & & & + & + & & 1 & + & 4 & 40 \\
\hline Annonaceae & Msph & G & Ballo & Gilb & Xylopia staudtii Engl. \& Diels & $\mathrm{s}$ & & & + & & + & & & + & & & 3 & 30 \\
\hline \multicolumn{19}{|c|}{ Hyparrhenietea Schmitz 1963} \\
\hline Sapindaceae & PhL & Aam & Sarco & Hypar & Cardiospermum halicacabum L. & 1 & & & & & & & & & & + & 1 & 10 \\
\hline Leguminosae & Mcph & Aam & Ptero & Hypar & Entada africana Guill. \& Perr. & $\mathrm{s}$ & & & + & & & & & & & + & 2 & 20 \\
\hline Poaceae & H-caesp & At & Sclero & Hypar & Hyparrhenia diplandra (Hack.) Stapf & $\mathrm{h}$ & & & & & & & & & & + & 1 & 10 \\
\hline Hernandiaceae & PhL & At & Ptero & Hypar & Illigera pentaphylla Welw. & 1 & & & & & + & & & & + & & 2 & 20 \\
\hline Hernandiaceae & PhL & At & Ptero & Hypar & Illigera vespestilio(Benth.) Baker $\mathrm{f}$. & 1 & & & & + & & & & & + & + & 3 & 30 \\
\hline Verbenaceae & Nnph & At & Ptero & Hypar & Lippia adoensis(Hochst. ex Walp.) & us & & & & & & & & & & + & 1 & 10 \\
\hline Asteraceae & T-erec & At & Pogo & Hypar & Microglossa pyrifolia (Lam.) O. Ktze & $\mathrm{h}$ & & & & & & & & & & + & 1 & 10 \\
\hline Rubiaceae & T-erec & G & Sclero & Hypar & Mitracapus scaber Zucc. & $\mathrm{h}$ & & & & & & & & & & + & 1 & 10 \\
\hline Rubiaceae & PhL & $\mathrm{Cg}$ & Sarco & Hypar & Mussaenda arcuata Lam. ex Poir. & 1 & & & & & & & + & & & + & 2 & 20 \\
\hline
\end{tabular}

J. Makemteu and E. Noumi (2020) / Characterization of plant groups and description of plant succession in the sacred Kouoghap forest of the Batoufam village, West 


\begin{tabular}{|c|c|c|c|c|c|c|c|c|c|c|c|c|c|c|c|c|c|c|}
\hline Families & BT & PT & DDT & EG & species & Strat & R1 & $\mathbf{R 2}$ & $\mathbf{R 3}$ & R4 & $\mathbf{R} \mathbf{5}$ & R6 & $\mathbf{R}_{7}$ & $\mathbf{R 8}$ & R9 & R10 & $\mathbf{P}$ & $\mathbf{F}$ \\
\hline Davalliaceae & G-rhiz & At & Sclero & Hypar & Nephrolepis undulata (Afzel. ex Sw.) J.Sm. var. undulata & $\mathrm{h}$ & & & & & & & & & & + & 1 & 10 \\
\hline Poaceae & H-caesp & Pan & Pogo & Hypar & Pennisetum purpureum Schumach, & $\mathrm{h}$ & & & & & & & + & & + & & 2 & 20 \\
\hline Leguminosae & Nnph & At & Ballo & Hypar & Pseudarthria hookerri Wighter \& Arn. var. hookeri & $\mathrm{h}$ & & & & & & & & & & + & 1 & 10 \\
\hline Poaceae & H-prost & $\mathrm{Cg}$ & Pogo & Hypar & Setaria megaphylla (Steud.) T. Durand \& Schinz & $\mathrm{h}$ & + & & + & & + & & & & & & 3 & 30 \\
\hline Fabaceae & Nnph & G & Ballo & Hypar & Tephrosia vogellii Hook.f. & us & & & + & & & & & & & + & 2 & 20 \\
\hline Euphorbiaceae & $\mathrm{PhL}$ & G & Sarco & Hypar & Tragia senegalensis Müll.Arg. & l & & & & & & & & & & + & 1 & 10 \\
\hline Poaceae & H-rept & Pan & Sclero & Hypar & Oplismenus burmanii (Retz) P. Beauv & $\mathrm{h}$ & + & + & + & + & + & & & & + & + & 7 & 70 \\
\hline \multicolumn{19}{|c|}{ Musango-Terminalietea, Lebrun et Gilbert 1954} \\
\hline Zingiberaceae & G-rhiz & G & Sarco & Mus & Aframomum daniellii (Hook.f.) K. Schum. & $\mathrm{h}$ & + & + & + & + & 2 & + & + & 1 & + & 2 & 10 & 100 \\
\hline Bignoniaceae & Msph & G-Sz & Ptero & Mus & Markhamia tomentosa (Benth.) K. Schum.ex Engl. & $\mathrm{s}$ & 3 & 2 & 3 & 2 & 2 & 2 & 1 & 2 & 2 & + & 10 & 100 \\
\hline Leguminosae & PhL & G & Ballo & Mus & Acacia pennata Wild. & 1 & 3 & 2 & + & + & & 2 & 2 & + & 2 & 1 & 9 & 90 \\
\hline Moraceae & Msph & $\mathrm{Cg}$ & Sarco & Mus & Trilepisium madagascariense DC. & $\mathrm{T}$ & 2 & 1 & 2 & 2 & 2 & 1 & 2 & 2 & 1 & 1 & 10 & 100 \\
\hline Apocynaceae & Mcph & $\mathrm{Cg}$ & Sarco & Mus & Rauvolfia macrophylla Stapf & $\mathrm{s}$ & + & + & + & + & & + & 1 & + & + & + & 9 & 90 \\
\hline Apocynaceae & Msph & G-Sz & Pogo & Mus & Funtumia africana (Benth.) Stapf & $\mathrm{s}$ & 2 & 1 & 2 & 3 & 1 & 2 & & 2 & + & & 8 & 80 \\
\hline Leguminosae & PhL & G-Sz & Ptero & Mus & Dalbergia hostilis Benth. & 1 & & + & + & + & & + & & + & 1 & + & 7 & 70 \\
\hline Vitaceae & PhL & G-Sz & Sarco & Mus & Ampelocissus bombycina (Bak.) Planch. & 1 & & + & & & & + & & & & + & 3 & 30 \\
\hline Araceae & G-rhiz & Aam & Sarco & Mus & Anchomanes difformis Engl. & $\mathrm{h}$ & + & & & & & & + & & + & & 3 & 30 \\
\hline Loganiaceae & Msph & G-Sz & Sarco & Mus & Anthocleista schweinfurthii Gilg. & $\mathrm{T}$ & & & & + & + & & + & & & & 3 & 30 \\
\hline Loganiaceae & Mcph & $\mathrm{G}$ & Sarco & Mus & Anthocleista vogelii Planch. & $\mathrm{s}$ & & & + & & & & & & & & \begin{tabular}{|l|l|}
1 \\
\end{tabular} & 10 \\
\hline Costaceae & G-rhiz & G & \begin{tabular}{|l|} 
Sarco \\
\end{tabular} & Mus & Costus afer Ker-Gawl & $\mathrm{h}$ & & & + & & & & & & & + & 2 & 20 \\
\hline Costaceae & G-rhiz & G & Sarco & Mus & Costus lucanusianus J. Br. \& K. Schum. & $\mathrm{h}$ & & & & & & & & & & + & 1 & 10 \\
\hline Fabaceae & PhL & G-Sz & Ballo & Mus & Dalbergia saxatilis Hook. & 1 & & & + & + & + & & & & & + & 4 & 40 \\
\hline Dichapetalaceae & Mcph & $\mathrm{Cg}$ & Sarco & Mus & Dichapetalum angolense Chodat & $\mathrm{s}$ & & & & & & & & & & + & 1 & 10 \\
\hline Dioscoreaceae & G-rad & At & Ptero & Mus & Dioscorea bulbifera L. & l & & & & & & & & & + & + & 2 & 20 \\
\hline Dioscoreaceae & G-rad & Ind & Ptero & Mus & Dioscorea sp. & 1 & + & + & + & & + & & + & + & + & & 7 & 70 \\
\hline Sterculiaceae & Msph & G & Ptero & Mus & Dombeya buettneri K. Schum. & $\mathrm{T}$ & & + & & & & + & + & & + & + & 5 & 50 \\
\hline Myrtaceae & Nnph & G & Sarco & Mus & Eugenia afzelii Engl. & us & & & & & & & & & & + & 1 & 10 \\
\hline Moraceae & Mcph & G & Sarco & Mus & Ficus artocarpoïdes Warb. & $\mathrm{T}$ & & & + & & + & & & + & & & 3 & 30 \\
\hline Moraceae & Msph & $\mathrm{Pal}$ & Sarco & Mus & Ficus exasperata Vahl & $\mathrm{s}$ & & & 1 & & 1 & & 1 & + & 1 & & 5 & 50 \\
\hline Moraceae & Mcph & G-Sz & Sarco & Mus & Ficus natalensis Hochst & $\mathrm{s}$ & & & + & & & + & & & + & & 3 & 30 \\
\hline Moraceae & PhL & $\mathrm{Cg}$ & Sarco & Mus & Ficus ottonïfolia (Miq.) Miq. & l & & + & + & + & + & & & & + & + & 6 & 60 \\
\hline Moraceae & Msph & G-Sz & Sarco & Mus & Ficus trichopoda Bak. & $\mathrm{s}$ & & + & & & & + & & & & & 2 & 20 \\
\hline Hypericaceae & Mcph & At & \begin{tabular}{|l|} 
Sarco \\
\end{tabular} & Mus & Harungana madagascariensis Lam.ex Poit. & $\mathrm{s}$ & & + & & & & & & & & + & 2 & 20 \\
\hline Lamiaceae & T-erec & G-Sz & Sclero & Mus & Leucas maretinicensis (Jacq.) Ait.f. & $\mathrm{h}$ & & & & & & & & & & + & 1 & 10 \\
\hline Acanthaceae & Nnph & G & Ballo & Mus & Acanthus montanus (Nees) T. Anders & $\mathrm{h}$ & & & + & & + & & & & & & 2 & 20 \\
\hline Moraceae & Mcph & $\mathrm{Cg}$ & Sarco & Mus & Milicia excelsa (Welx.) C. C. Berg. & $\mathrm{T}$ & & + & & + & & & & & & & 2 & 20 \\
\hline Cucurbitaceae & \begin{tabular}{|l|l|l|l} 
ThL \\
\end{tabular} & At & Sarco & Mus & Momordica cissoïdes Planch.ex. Benth. & 1 & & + & & & + & & & & + & + & 4 & 40 \\
\hline Moringaceae & Mcph & Aas & Ballo & Mus & Moringa oleifera Lam. & $\mathrm{s}$ & & & & & & & & & & + & 1 & 10 \\
\hline Euphorbiaceae & Msph & $\mathrm{Cg}$ & Sarco & Mus & Neoboutonia africana Müll. Arg. & $\mathrm{S}$ & + & & & & & & & & & & 1 & 10 \\
\hline Leguminosae & Mcph & $\mathrm{G}$ & Ballo & Mus & Pentaclethra macrophylla Benth. & $\mathrm{s}$ & & & & & & + & & & + & & 2 & 20 \\
\hline Lauraceae & Mcph & Aam & Sarco & Mus & Persea americana Mill. & $\mathrm{T}$ & & & & & & & & & & + & 1 & 10 \\
\hline Myrtaceae & Nnph & Pan & Sarco & Mus & Psidium guajava L. & \begin{tabular}{|l|l}
$\mathrm{s}$ \\
\end{tabular} & & & & & & & & & & + & 1 & 10 \\
\hline Pteridaceae & G-rhiz & $\mathrm{G}$ & \begin{tabular}{|l|} 
Sclero \\
\end{tabular} & Mus & Pteris barombensis Hier. & $\mathrm{h}$ & & & & & + & & & + & & & 2 & 20 \\
\hline
\end{tabular}

J. Makemteu and E. Noumi (2020) / Characterization of plant groups and description of plant succession in the sacred Kouoghap forest of the Batoufam village, West 


\begin{tabular}{|c|c|c|c|c|c|c|c|c|c|c|c|c|c|c|c|c|c|c|}
\hline Families & BT & PT & DDT & EG & species & Strat & $\mathbf{R 1}$ & R2 & R3 & R4 & $\mathbf{R} \mathbf{5}$ & R6 & $\mathbf{R}_{7}$ & $\mathbf{R 8}$ & R9 & R10 & $\mathbf{P}$ & $\mathbf{F}$ \\
\hline Apocynaceae & Mcph & $\mathrm{Cg}$ & Sarco & Mus & Rauvolfia africanaAfzl. & us & & & & + & + & & & & & & 2 & 20 \\
\hline Apocynaceae & Mcph & $\mathrm{G}$ & Sarco & Mus & Rauvolfia vomitoria Afz. & $\mathrm{s}$ & & & + & & + & & + & & & + & 4 & 40 \\
\hline Solanaceae & Nnph & G & Sarco & Mus & Solanum aculeastrum Dunal var. albifolium & $\mathrm{S}$ & & & & & & & & & & + & 1 & 10 \\
\hline Bignoniaceae & Msph & At & Ptero & Mus & Spathodea campanulata P. Beauv. & $\mathrm{T}$ & & & & & & & + & + & & & 2 & 20 \\
\hline Dilleniaceae & $\mathrm{PhL}$ & G & Sarco & Mus & Tetracera alniflolia Willd. subsp. alnifolia & 1 & & + & & & + & 1 & + & & & + & 5 & 50 \\
\hline Dilleniaceae & Mcph & At & Sarco & Mus & Tetracera micrantha (Hochst.) Baillon & 1 & & & & & & + & & & + & & 2 & 20 \\
\hline Rhamnaceae & $\mathrm{PhL}$ & G & Sarco & Mus & Ventilago africana Exell & 1 & & & & & & & & & & + & 1 & 10 \\
\hline Asteraceae & Mcph & $\mathrm{Am}$ & Pogo & Mus & Vernonia conferta Benth. & $\mathrm{s}$ & + & + & & & & + & & + & + & & 5 & 50 \\
\hline Asteraceae & Nnph & G & Pogo & Mus & Vernonia richardiana (O. Ktze) P. & us & & & & & & & & & & + & 1 & 10 \\
\hline \multicolumn{19}{|c|}{ Mitragynetea Schmitz 1963} \\
\hline Acanthaceae & Ch-erec & G & Sclero & Mytra & Brillantaisia debilis Burkill & $\mathrm{h}$ & & & & & & & & & & + & 1 & 10 \\
\hline Acanthaceae & Ch-erec & At & Sclero & Mytra & Brillantaisia nitens Lind. & $\mathrm{h}$ & + & & & + & + & + & & & & & 4 & 40 \\
\hline Acanthaceae & Ch-erec- & G & Sclero & Mytra & Brillantaisia owariensis P. Beauv & $\mathrm{h}$ & & & + & + & & & & & & + & 3 & 30 \\
\hline Ochnaceae & Nnph & $\mathrm{Cg}$ & Sarco & Mytra & Campylospermum flavum (Schumach. \& Thonn.) Farron & $\mathrm{S}$ & & & + & + & + & & & & & & 3 & 30 \\
\hline Asparagaceae & G-bulb & Amo & Ballo & Mytra & Chlorophytum cf orcidastrum Lindl. & $\mathrm{h}$ & + & & & & & & & & & + & 2 & 20 \\
\hline Leguminosae & Mcph & G-Sz & Ballo & Mytra & Erythrina senegalensis DC. & $\mathrm{S}$ & & & & & + & & & + & & & 2 & 20 \\
\hline Moraceae & Mcph & G & Sarco & Mytra & Ficus mucuso Ficalho & $\mathrm{T}$ & & & + & + & & & & & & & 2 & 20 \\
\hline Phyllanthaceae & Nnph & $\mathrm{Cg}$ & Sarco & Mytra & Hymenocardia heudelotii Müll. Arg. & $\mathrm{s}$ & & & & & & & & & & + & 1 & 10 \\
\hline Anacardiaceae & Msph & $\mathrm{G}$ & Sarco & Mytra & Lannea welwitschii (Hiern) Engl. & $\mathrm{T}$ & & & & & & & & & & + & 1 & 10 \\
\hline Anacardiaceae & Msph & $\mathrm{Am}$ & Sarco & Mytra & Pseudospondias microcarpa (A. Rich.) Engl. & $\mathrm{T}$ & & & & + & + & & & & + & + & 4 & 40 \\
\hline Sterculiaceae & Msph & Pra & Sarco & Mytra & Sterculia tragacantha Lindl. & $\mathrm{s}$ & 1 & + & + & 1 & 1 & + & 2 & 1 & 1 & 1 & 10 & 100 \\
\hline Apocynaceae & $\mathrm{PhL}$ & $\mathrm{Am}$ & Pogo & Mytra & Tylophora sylvatica Decne & 1 & & + & + & + & & + & & & + & + & 6 & 60 \\
\hline Arecaceae & Mcph & Pal & Sarco & Mytra & Elaeis guineensis Jacq. & $\mathrm{S}$ & & + & + & + & & + & + & & + & + & 7 & 70 \\
\hline \multicolumn{19}{|c|}{ Oleo-Jasminetalia Lebrun et Gilbert 1954} \\
\hline Athyriaceae & G-rhiz & Aas & Sclero & Oleo & Athyrium schimperi Moug, ex Fee & $\mathrm{S}$ & & & & + & & & & & & & 1 & 10 \\
\hline Rubiaceae & Mcph & Pan & Sarco & Oleo & Canthium vulgare (K. Schum.) Bullock & $\mathrm{S}$ & + & & + & & & & & & & & 2 & 20 \\
\hline Vitaceae & $\mathrm{PhL}$ & G & Sarco & Oleo & Cissus aralioides (Welw.ex Bak.) Planch. & 1 & + & & & & & & & & + & + & 3 & 30 \\
\hline Ranunculaceae & $\mathrm{PhL}$ & Amo & Pogo & Oleo & Clematis hirsuta Guill. \& Perr. & 1 & & & + & + & & & & & & + & 3 & 30 \\
\hline Burseraceae & Mcph & G-Sz & Sarco & Oleo & Commiphora africana (A. Rich.) Engl. & $\mathrm{S}$ & & & & & & & & & & + & 1 & 10 \\
\hline Oleaceae & T-erec & G-Sz & Sarco & Oleo & Jasminum dichotomum Vahl. & l & & & + & & & & & & & + & 2 & 20 \\
\hline Poaceae & H-prot & G & Pogo & Oleo & Rhynchelytrum repens (Willd.) C.E. Bubbard & $\mathrm{h}$ & & & & & & & & & & + & 1 & 10 \\
\hline Orchidaceae & H-E & G & Sclero & Oleo & Tridactyle tridactylites (Rolfe) Schltr. & ep & & & + & & + & & & & & & 2 & 20 \\
\hline Hypericaceae & Nnph & G & Sarco & Oleo & Vismia rubescensOliv. & $\mathrm{s}$ & & & & + & & & & & & + & 2 & 20 \\
\hline Cucurbitaceae & T-L & Pan & Sarco & Oleo & Zehneria scabra (L.f.) Sander & 1 & & & & & & + & & & & + & 2 & 20 \\
\hline \multicolumn{19}{|c|}{ Phragmitetea Tüxen \& Preising } \\
\hline Cyperaceae & G-rhiz & $\mathrm{Am}$ & Sclero & Phra & Scleria racemosa subsp. Depressa (CB. Cl) J. Raynal & $\mathrm{h}$ & & & & + & & & & & & & 1 & 10 \\
\hline \multicolumn{19}{|c|}{ Piptadeniastro-Celtidetalia } \\
\hline Connaraceae & PhL & Ind & Ballo & Pip & Agelaea sp. & 1 & + & & & & & & & & + & + & 3 & 30 \\
\hline Leguminosae & Msph & $\mathrm{Cg}$ & \begin{tabular}{|l|} 
Ptero \\
\end{tabular} & Pip & Amphimas ferrugineus Pierre ex Pellegr. & $\mathrm{T}$ & & & + & & & & & & & & 1 & 10 \\
\hline Lomariopsidaceae & G-rhiz & $\mathrm{Am}$ & Sclero & Pip & Bolbitis acrostichoides (Afz. ex Sw,) Ching & $\mathrm{h}$ & + & & + & & + & & & & & & 3 & 30 \\
\hline Celtidaceae & Mcph & G & Sarco & Pip & Celtis gomphophylla Bak. & $\mathrm{T}$ & & & & + & & & + & & + & + & 4 & 40 \\
\hline Celtidaceae & Mcph & $\mathrm{Cg}$ & Sarco & Pip & Celtis integrifolia Lam. & $\mathrm{S}$ & & & & & & & & & & + & 1 & 10 \\
\hline
\end{tabular}

J. Makemteu and E. Noumi (2020) / Characterization of plant groups and description of plant succession in the sacred Kouoghap forest of the Batoufam village, West 


\begin{tabular}{|c|c|c|c|c|c|c|c|c|c|c|c|c|c|c|c|c|c|c|}
\hline Families & BT & PT & DDT & EG & species & Strat & $\mathbf{R 1}$ & R2 & $\mathbf{R 3}$ & $\mathbf{R 4}$ & $\mathbf{R} \mathbf{5}$ & $\mathbf{R 6}$ & $\mathbf{R}_{7}$ & $\mathbf{R 8}$ & R9 & R10 & $\mathbf{P}$ & $\mathbf{F}$ \\
\hline Sapotaceae & Msph & Ind & Sarco & Pip & Chrysophyllum sp. & $\mathrm{S}$ & + & & & & & & & & & & 1 & 10 \\
\hline Connaraceae & $\mathrm{PhL}$ & G & Sarco & Pip & Cnestis ferruginea DC. & us & + & + & + & & & & & & & & 3 & 30 \\
\hline Connaraceae & PhL & G & Sarco & Pip & Cnestis urens Gilg. & us & + & & & & & & & & + & & 2 & 20 \\
\hline Sterculiaceae & Mcph & $\mathrm{Cg}$ & Sarco & Pip & Cola acuminata (P. Beauv.) Schott. \& Engl. & $\mathrm{s}$ & & & & & & & & & + & + & 2 & 20 \\
\hline Combretaceae & $\mathrm{PhL}$ & $\mathrm{G}$ & Ptero & Pip & Combretum dolichopetalum Engl. \& Diels & 1 & & & + & + & & & & & & + & 3 & 30 \\
\hline Combretaceae & PhL & G-Sz & Ptero & Pip & Combretum hispidum Laws & 1 & + & & & & & & & & + & 1 & 3 & 30 \\
\hline Combretaceae & PhL & $\mathrm{Cg}$ & Ptero & Pip & Combretum hypopilinum Diels & 1 & & & & & & & & & & + & 1 & 10 \\
\hline Combretaceae & PhL & At & Ptero & Pip & Combretum paniculatum Vent & 1 & & 2 & & & & & & & & & 1 & 10 \\
\hline Combretaceae & PhL & Ind & Ptero & Pip & Combretum sp. & 1 & & & & & + & & & + & & & 2 & 20 \\
\hline Leguminosae & Msph & At & Baro & Pip & Copaifera mildbraedii Harms & $\mathrm{T}$ & & & & + & + & & & + & & & 3 & 30 \\
\hline Vitaceae & Mcph & At & Sarco & Pip & Cyphostemma adenocaule (Steud.) Descoing & 1 & & & & & & & & & & + & 1 & 10 \\
\hline Leguminosae & PhL & $\mathrm{Cg}$ & Baro & Pip & Entada gigas (L.) Fawcett \& Rendle & 1 & + & & + & + & + & & & + & + & & 6 & 60 \\
\hline Meliaceae & Msph & $\mathrm{Cg}$ & Ballo & Pip & Entandrophragma utile (Dawe \& Sprague) Sprague & $\mathrm{T}$ & & & & & & & & + & + & & 2 & 20 \\
\hline Samydaceae & Msph & $\mathrm{Cg}$ & Sarco & Pip & Homalium dolichophyllum Gilg & $\mathrm{s}$ & & & & & & & & & & + & 1 & 10 \\
\hline Verbenaceae & Msph & $\mathrm{Cg}$ & Sarco & Pip & Vitex grandifolia Gürke & $\mathrm{S}$ & 1 & + & 1 & + & 1 & + & 2 & 1 & 2 & 1 & 10 & 100 \\
\hline Apocynaceae & PhL & G-Sz & Sarco & Pip & Landolphia owarensis P. Beauv. & 1 & + & & + & + & + & + & + & + & + & + & 9 & 90 \\
\hline Meliaceae & Msph & G & Sarco & Pip & Trichilia rubescens Oliv. & $\mathrm{s}$ & & + & 2 & 2 & 1 & 1 & 2 & + & & & 7 & 70 \\
\hline Ochnaceae & Mcph & G & Sarco & Pip & Ochna afzelii R. Br.ex Oliv. & $\mathrm{s}$ & + & + & + & & + & + & & & + & + & 7 & 70 \\
\hline Leguminosae & Mcph & At & Ballo & Pip & Hymenostegia breteleri Aubr. & $\mathrm{T}$ & 1 & & + & + & & 1 & + & + & + & & 7 & 70 \\
\hline Lauraceae & Mcph & $\mathrm{Cg}$ & Sarco & Pip & Hypodaphnis zenkeri (Engl.) Stapf & $\mathrm{S}$ & & + & + & + & & + & + & & & + & 6 & 60 \\
\hline Asteraceae & Th(erec) & $\mathrm{G}$ & Pogo & Pip & Lactuca capensis Thunb. & $\mathrm{h}$ & & & & & & & & & & + & 1 & 10 \\
\hline Sapindaceae & Msph & G & Sarco & Pip & Lecaniodiscus cupanioides Planch.ex Benth. & $\mathrm{T}$ & & & + & & & & & & + & + & 3 & 30 \\
\hline Euphorbiaceae & Mcph & $\mathrm{G}$ & Sarco & Pip & Mallotus oppositifolius (Geisel) Müll. Arg. & $\mathrm{s}$ & & & & & & 1 & & & 1 & & 2 & 20 \\
\hline Bignoniaceae & Mcph & G & Ptero & Pip & Markhamia lutea (Benth.) K. Schum. & $\mathrm{s}$ & & & 1 & + & + & & + & & & & 4 & 40 \\
\hline Annonaceae & Mcph & G-Sz & Sarco & Pip & Monodora myristica Gaertn. Dunal & $\mathrm{s}$ & & & + & & + & & 1 & & + & + & 5 & 50 \\
\hline Cecropiaceae & Msph & G & Sarco & Pip & Myrianthus arboreus P. Beauv. & $\mathrm{S}$ & & & & & & & & & & + & 1 & 10 \\
\hline Commelinaceae & Ch-erec & $\mathrm{Cg}$ & Sclero & Pip & Palisota ambigua (P. Beauv.) C. B. Cl. & $\mathrm{h}$ & + & 1 & & & & + & + & & + & + & 6 & 60 \\
\hline Leguminosae & Msph & $\mathrm{Cg}$ & Baro & Pip & Parkia bicolor A. Chev. & $\mathrm{s}$ & & + & & & & & + & & & + & 3 & 30 \\
\hline Piperaceae & Nnph & G-Sz & Sarco & Pip & Piper capense L. & $\mathrm{h}$ & & & & + & + & & + & & & + & 4 & 40 \\
\hline Piperaceae & PhL & Pan & Sarco & Pip & Piper umbellatum L. & $\mathrm{h}$ & & & & & & & + & & & + & 2 & 20 \\
\hline Leguminosae & Msph & G & Ptero & Pip & Piptadeniastrum africanum (HooK. f.) Brenan & $\mathrm{T}$ & & + & + & + & + & & & + & & & 5 & 50 \\
\hline Polypodiaceae & G-rhiz-E & At & Sclero & Pip & Platycerium angolensis Welw.ex. Hooker & ep & & & + & & & & & & & & 1 & 10 \\
\hline Leguminosae & Mcph & $\mathrm{Cg}$ & Ptero & Pip & Pterocarpus mildbraedii Engl. & $\mathrm{T}$ & & & & & + & & & + & & & 2 & 20 \\
\hline Leguminosae & Msph & G & Ptero & Pip & Pterocarpus soyauxii Taub. & $\mathrm{T}$ & & & & & & & & & & + & 1 & 10 \\
\hline Euphorbiaceae & $\mathrm{PhL}$ & $\mathrm{Cg}$ & Sarco & Pip & Sapium cornutum var. Cociaceum Pax & 1 & + & & & & & + & & & + & & 3 & 30 \\
\hline Meliaceae & Msph & $\mathrm{G}$ & Sarco & Pip & Sorindeia grandifolia Engl. & us & & & & & & & + & + & + & & 3 & 30 \\
\hline Anacardiaceae & Nnph & Ind & Sarco & Pip & Sorindeia sp. & $\mathrm{s}$ & & & & & & & & & + & & 1 & 10 \\
\hline Rutaceae & Mcph & $\mathrm{Cg}$ & Sarco & Pip & Teclea afzelli Engl. & $\mathrm{S}$ & & & & & & + & + & & & & 2 & 20 \\
\hline \multicolumn{19}{|c|}{ Polyscietalia fulvae Lebrun et Gilbert 1954} \\
\hline Alangiaceae & Mcph & Pal & Sclero & Polys & Alangium Chinense (Lour.) Harms & $\mathrm{s}$ & & & & + & & & & & & & 1 & 10 \\
\hline Euphorbiaceae & Msph & G & Ballo & Polys & Croton macrostachyus Hochst ex Del. & $\mathrm{T}$ & & & & + & + & & + & & & + & 4 & 40 \\
\hline Rhamnaceae & PhL & At & Ptero & Polys & Gouania longipetala Hemls. & 1 & & + & & + & + & + & & & + & 1 & 6 & 60 \\
\hline Euphorbiaceae & Msph & $\mathrm{G}$ & Sarco & Polys & Macaranga occidentalis (Müll. Arg.) Müll. Arg. \& Serr & $\mathrm{S}$ & + & 1 & + & + & & + & + & + & + & 2 & 9 & 90 \\
\hline Araliaceae & Msph & At & Sarco & Polys & Polyscias fulva (Hiern.) Harms & $\mathrm{T}$ & 1 & & 1 & 3 & 2 & 1 & 1 & 1 & + & 2 & 9 & 90 \\
\hline Myrsinaceae & Mcph & $\mathrm{Am}$ & Sarco & Polys & Maesa lanceolata Forsk. & $\mathrm{s}$ & & & & & & & & & & + & 1 & 10 \\
\hline
\end{tabular}

J. Makemteu and E. Noumi (2020) / Characterization of plant groups and description of plant succession in the sacred Kouoghap forest of the Batoufam village, West 


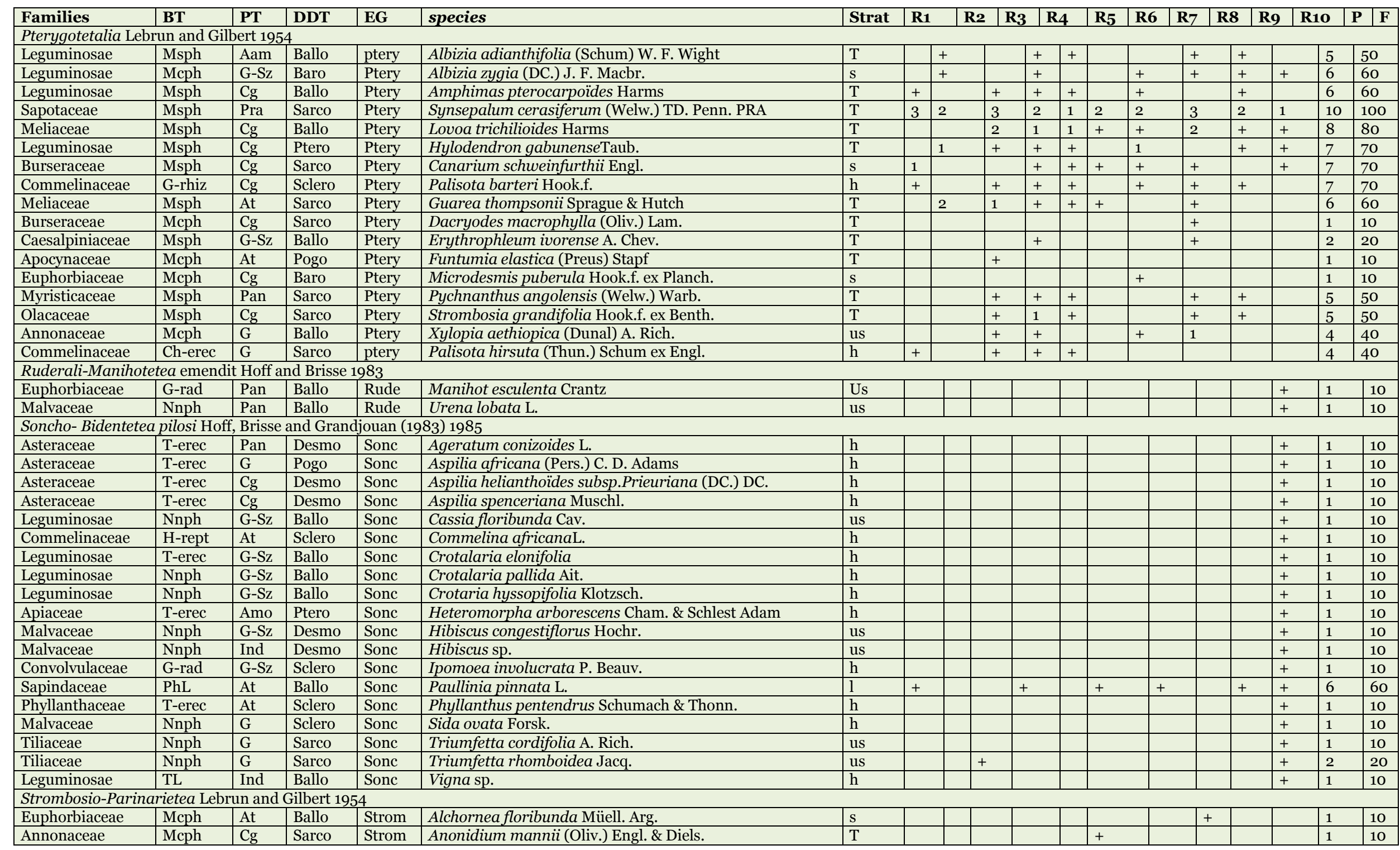

J. Makemteu and E. Noumi (2020) / Characterization of plant groups and description of plant succession in the sacred Kouoghap forest of the Batoufam village, West Cameroon 


\begin{tabular}{|c|c|c|c|c|c|c|c|c|c|c|c|c|c|c|c|c|c|c|}
\hline Families & BT & PT & DDT & EG & \begin{tabular}{|l|} 
species \\
\end{tabular} & Strat & $\mathbf{R 1}$ & $\mathbf{R 2}$ & $\mathbf{R 3}$ & $\mathbf{R 4}$ & $\mathbf{R 5}$ & R6 & $\mathbf{R}_{7}$ & $\mathbf{R 8}$ & R9 & R10 & $\mathbf{P}$ & $\mathbf{F}$ \\
\hline Aspleniaceae & Ch-E & At & Sarco & Strom & Asplenium africanum Desv. & ep & & & & + & & & & & & & 1 & 10 \\
\hline Aspleniaceae & Ch-E & At & Sclero & Strom & Asplenium buettneri Hier. Ex Brause & ep & & & + & & + & & & & & & 2 & 20 \\
\hline Aspleniaceae & Ch-E & G-Sz & Sclero & Strom & Asplenium nidus L. & ep & + & & & & & + & & & & & 2 & 20 \\
\hline Euphorbiaceae & Msph & G-Sz & Sarco & Strom & Bridelia micrantha (Hochst) Baill. & $\mathrm{s}$ & + & & & & & + & & & & & 2 & 20 \\
\hline Meliaceae & Mcph & G & Sarco & Strom & Carapa procera DC. & $\mathrm{s}$ & & & + & + & + & & + & + & & & 5 & 50 \\
\hline Verbenaceae & $\mathrm{PhL}$ & At & Ptero & Strom & Clerodendrum paniculatum Vent. & 1 & 1 & & & + & & & & & + & & 3 & 30 \\
\hline Asteraceae & $\mathrm{PhL}$ & $\mathrm{Cg}$ & Ballo & Strom & Coreopsis parviflora Jacq. & 1 & & & & & & & & & & + & 1 & 10 \\
\hline Rubiaceae & Nnph & $\mathrm{Cg}$ & Sarco & Strom & Cremaspora triflora (Thonn.) K. Schum. & 1 & & & & & + & + & & & + & + & 4 & 40 \\
\hline Araceae & $\mathrm{PhL}$ & $\mathrm{Cg}$ & Sarco & Strom & Culcasia obliquifolia Engl. & $\mathrm{h}$ & & & + & & & & & + & & & 2 & 20 \\
\hline Araceae & $\mathrm{PhL}$ & $\mathrm{Cg}$ & Sarco & Strom & Culcasia tenuifolia Engl, & $\mathrm{h}$ & & & & & & + & & & & + & 2 & 20 \\
\hline Burseraceae & Msph & $\mathrm{Cg}$ & Sarco & Strom & Dacryodes igagangaAubr. \& Pellegr. & $\mathrm{T}$ & & & & & & & & & 2 & + & 2 & 20 \\
\hline Dracaenaceae & Nnph & G & Sarco & Strom & Draceana deisteliana Engl. & $\mathrm{s}$ & 3 & 2 & 1 & 2 & 1 & 2 & 1 & 2 & 1 & 1 & 10 & 100 \\
\hline Euphorbiaceae & Msph & Pan & Baro & Strom & Sapium ellipticum (Hochst.) Pax & $\mathrm{T}$ & & & + & & + & + & + & & + & 1 & 6 & 60 \\
\hline Aspleniaceae & $\mathrm{H}-\mathrm{E}$ & $\mathrm{Cg}$ & Sclero & Strom & Asplenium biaframum & ep & + & + & + & + & & + & & & + & & 6 & 60 \\
\hline Moraceae & Mcph & $\mathrm{Cg}$ & Sarco & Strom & Ficus abscondita C. C. Berg. & $\mathrm{s}$ & & & & & + & + & & + & + & & 4 & 40 \\
\hline Moraceae & Mcph & G & Sarco & Strom & Ficus thonningii Blume & $\mathrm{s}$ & & & + & + & & & + & & & & 3 & 30 \\
\hline Leeaceae & Nnph & G & Sarco & Strom & Leea guineensis G. Don & us & & & & & & & + & & + & + & 3 & 30 \\
\hline Celastraceae & Mcph & G-Sz & Sarco & Strom & Maytenus senegalensis (Lam.) Exell & $\mathrm{s}$ & & & & & & & & & & + & 1 & 10 \\
\hline Bignoniaceae & Msph & $\mathrm{Cg}$ & Ptero & Strom & Stereospermum acuminatissimum K. Schum & $\mathrm{T}$ & + & 1 & + & & & & + & & & & 4 & 40 \\
\hline Olacaceae & Mcph & Am & Sarco & Strom & Strombosia pustulata Oliv. & $\mathrm{s}$ & + & + & + & & & & & & & & 3 & 30 \\
\hline Loganiaceae & $\mathrm{PhL}$ & $\mathrm{Cg}$ & Sarco & Strom & Strychnos boonei De Wild. & 1 & & & + & & + & + & + & & & & 4 & 40 \\
\hline Loganiaceae & $\mathrm{PhL}$ & $\mathrm{Cg}$ & Sarco & Strom & Strychnos floribunda Gilg. & 1 & & & & & & & + & & + & & 2 & 20 \\
\hline & & & & & & & 60 & 53 & 97 & 80 & 76 & 60 & 69 & 68 & 85 & 157 & & \\
\hline
\end{tabular}

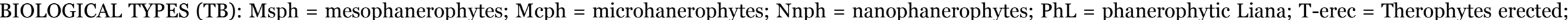

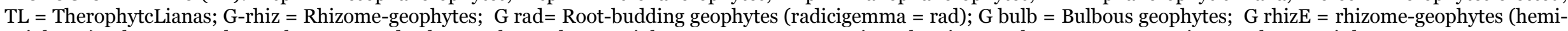

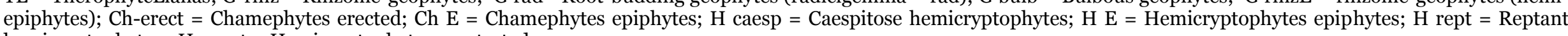
hemicryptophytes; H-prost = Hemicryptophytes prostrated;

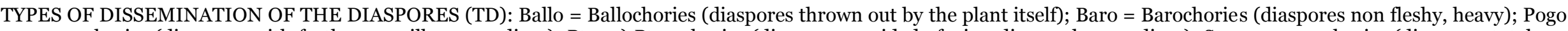

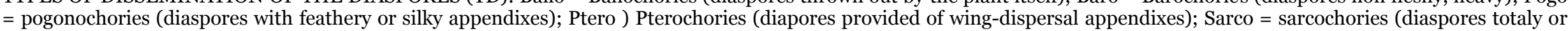
partially fleshy); Sclero = sclerochories (non fleshy diaspores, relatively light)

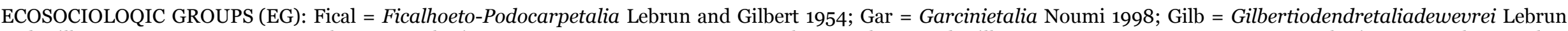

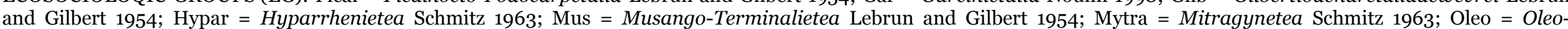

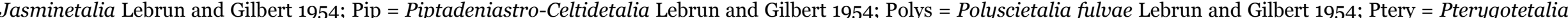

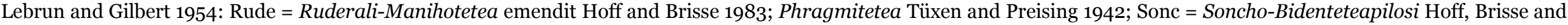
Grandjouan (19833) 1985; Strombosio-Parinarietea Lebrun and Gilbert 1954.

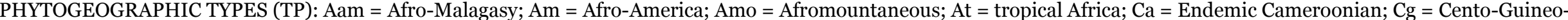
Congolian; G = Omni or subomni-Guineo-Congolian; G-Sz = Guineo-Sudano-Zambezian; Pal = Paleotropical; Pant = Pantropical.

STRATUM TYPES: Strat = stratum; $\mathrm{T}=$ Tree; $\mathrm{a}=$ shrub; $\mathrm{us}=$ under shelter; $\mathrm{h}=$ herbaceous; $\mathrm{l}=$ liana; ep = epiphyte.

J. Makemteu and E. Noumi (2020) / Characterization of plant groups and description of plant succession in the sacred Kouoghap forest of the Batoufam village, West 


\section{Ombrophile forest of Tricalysia macrophylla}

\section{Definition}

The grouping of Tricalyia macrophylla is an arborescent forestry vegetation, submountaneous, present in the Kouoghap sacral forest and also in the Guinean zone, in particular in Côte d'Ivoire, Togo, Nigeria and Gabon (Hallé, 1966). The floristic composition is given by 4 samplings ( $\mathrm{R}_{3}$, $\mathrm{R} 4, \mathrm{R} 5$ and R8) (Table 1). It is enough provided with plant species (145 species). The total number of species varies between 68 and 97 with an average of 97 species by sampling. The sampling type is represented by $\mathrm{R}_{3}$ and the characteristic of the association is Tricalysia macrophylla.

\section{Composition of floristics}

Tricalysia macrophylla K. Schum., Syn.: Tricalysia pluriovulata K. Schum., (Rubiaceae). The species reaches 10 to $15 \mathrm{~m}$ of height and 0.30 $\mathrm{m}$ of diameter in the dition; Fluted irregular trunk and contreforts; Leaf stalk pubescent in the juvenile stage. The limb is olive in colour, the barefaced grey, with an elliptic to oblong, form measuring 14-23 $\times$ 4-8 cm. Inflorescences occurs in small clusters of cymes, 10 floras or more, branched out from the the base. Globular fruits, of $5 \mathrm{~mm}$ of diameter, barefaced. Fruits are with thin pericarp, about thirty angular brown blackish seeds of $3.5 \mathrm{~mm}$ (Hallé, 1966). This species of forest reaches the biggest measurements met in the genus. The synthetic features in this association are: presence (100\%) and relative coverage (37.75\%).

Association-mate species: Draceana deisteliana and Psychotria vogeliana.

\section{Ecological spectra of the species of the gallery forest of Syncepalum cerasiferum}

The raw spectrum of the biological types of the species of the forests shows the predominance of the mesophanerophytes: $26.89 \%$ of the species. The nanophanerophytes only represents $8.96 \%$ of the species and the phanerophytic lianas $17.93 \%$ of species. Two hemicriptophytes are signalled. The spectrum of the dissemination types of the diaspores of the sempervirent orest shows the predomination of the sarcochories that represents $53.10 \%$ of the species. The barochories and the pogonochories are leact represented, respectively with $0.68 \%$ of species.

The raw spectrum of the ecosociological groups of species shows the predominance of the species of the low and middle altitude forests. When one considers the two orders solely (order of the Pterygotetalia Lebrun and Gilbert 1954 and of order of the Garcinietalia Noumi 1998) of which come out the characteristic species of the two associations described, their raw specters make 22.06\% of species. They don't dominate the raw spectrum of the ecosociological group's of the Kouoghap sylve (Table 1).

\section{Discussion}

The analysis of the phytogeographical distribution of the specific whole of this forest shows the dominance of the species belonging to the GuineoCongolese flora. The species of the sub-element omni-Guineo-Congolese are better represented. The most widespread diaspore types in the inventory are the Sarcochory of most plants of the arborescent stratum and the undergrowth (Evrard, 1968). The examination of biological types revealed the predominance of the microphanerophytes. The mesophanerophytes (19.25\%) make of Kouoghap a forest grouping of high cluster, characteristic of the vallicole forests (Lebrun and Gilbert, 1954). This forest of valley is an edaphic grouping and also physiographic grouping. It benefits from a favorable microclimate due to the constriction of the sides of the valley of the Lionlong River. The conditions are therefore auspicious to the good growth of the trees, reaching 30m of height, with the cylindrical and straight stems; from where the height raised of the dome. The samplings shows some particular species of PiptadenistroCeltidetalia (Albizia adianthifolia, Albizia zygia, Lovoa trichilioides, Hylodendron gabunense and Funtumia elastica), of the always green forest (Amphimas pterocarpoides, Dacryodes macrophylla and Erythrophleum ivorense) which are dominating species, descended of the Guinian various forestry types.

They become quickly familiar in the the northern zone, can be recovered in many places, especially in the gallerie forest. This floristic differentiation of the northern fringe of the semi - deciduous forest has already been described in Ghana, in coast of Ivory in 
Nigeria (Chipp, 1927; Mangenot, 1955; Taylor, 1960; Aubréville, 1959). It shows also some particular species in this northern zone of the semi-deciduous forest for the arborescent stratum, non met more at the South or at least with a least extension. This closeness between some species which appear bound to the particular conditions offered by the valley offered a core of individualisable grouping that we erected in plant association: the Synsepaletum cerasiferum ass. nov.

The main dynamic role is played within the plantation formation by species of the ombrophile and sempervirent forest that constitutes the forest "postclimax", relative to the succession, described in this work. Some species are found indifferently in the low and middle altitude vegetations, submountaneous and mountaneous vegetations. These species are part of the sylvan woody vegetation in African tropical and subtropical regions, of the class of the StrombosioParinarietea. The characteristic species of that class in the Kouoghap forest: Ficus thonningii, Strombosia pustulata, Dracaena fragrans, Strombosia grandifolia and Sapium ellipticum permit us to affiliate the Kouoghap sacral forest to thatphytosociological class. The species as Raphia farinifera, Xylopia rubescens, Cola verticillata, Ficus jansii, Draceana arborea and Gaertnea paniculata are characteristic of the order of the Garcinietalia Noumi 1998. Garcinia polyantha and Garcinia smeathmannii are the features that permit to affiliate the forest $\mathrm{cf}$ sempervirent of Kouoghap to the alliance of the Garcinion Noumi 1998.

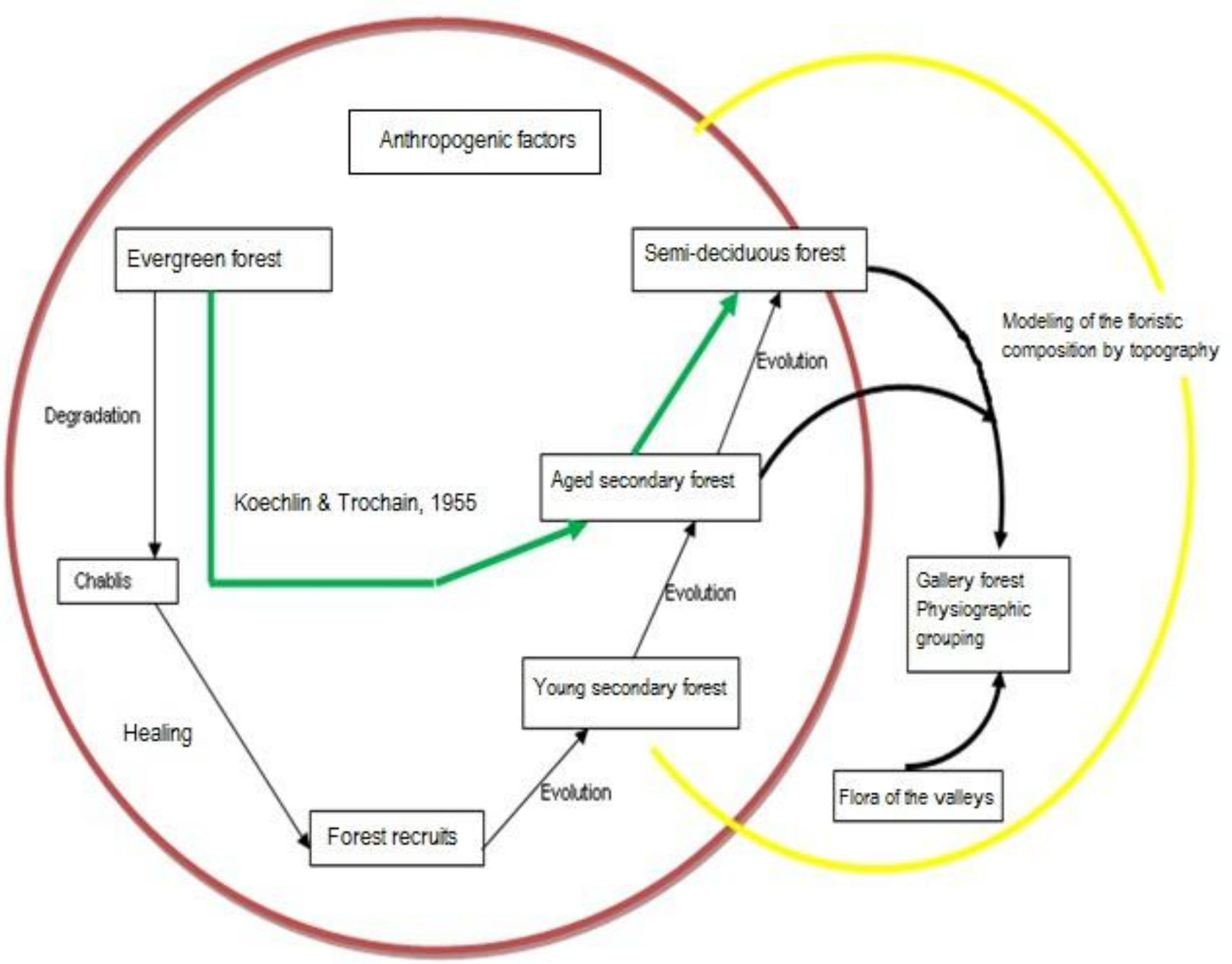

Fig. 7: Transformation of the rain forest demage to gallery forest. 
Tricalysia macrophylla is mentioned like characteristic of the association Tricalysietum macrophylla of the Garcinion. The information collected on the land permit to spread the area of this vegetation type and to raise it to the rank of association. If one refers to the area of extension of Tricalysia macrophylla (Hallé, 1966), one can think that this association is afrotropical. In Cameroon, it is signalled in the locality of Eseka (Zenker, 1898), to the South of the Nyong stream and to $200 \mathrm{~m}$ of altitude of a primary forest of Songbong (Leeuwenberg, 1965). It has also been harvested in the locality of Kribi and Eseka (Leeuwenberg, 1965) therefore the samples are available to the National herbarium of Cameroon (YA). In Africa, the species is signalled in Ivory Coast, Togo, Nigeria (Hallé, 1966).

The Kouoghap gallery forest, surrounded with the concession of the Batoufam population, contains some sudano-zambezian elements $(13.58 \%$ of the total of the species). This islet is a relic withfloristic composition shaped by the cf sempervirent relief forest of Tricalysia macrophylla. The elements of the latter are included currently in this regenerated forest: $16.6 \%$ of the total species belongs to the secondary forests and reaches a relative coverage of $26.80 \%$ ), that evolves toward the semidéciduous forest: $16.6 \%$ of the total of the species reaching a relative coverage of $8.86 \%$ ), herself, shaped by the relief in gallery forest: $6.42 \%$ of the total of the species reaching a relative coverage of $13.48 \%$ ). The studied formation is therefore a succession forest cf sempervirent - forest gallery. It is therefore a "postclimax' forester" of the gallery forest of the northern peripheral domain of the Guineo-Congolian region (Koechlin and Trochain, 1955; Letouzey, 1968). The totpographic localization of the old elements on the flank of the Kouoghap valley is an illutration of such a sequence given in Fig. 7 .

\section{Conclusion}

The poll of the flora of the Kouoghap sacral forest permitted to have visions of the succession forest $\mathrm{cf}$ sempervirente - forest gallery, that evolved to give the present stage. The fundamental floristic core of the forest is constituted of the ombrophile species, before the stages of succession. This grouping has been described in an association; the Tricalysietum macrophyllae ass. nov. The phenomena of the succession gave the typical grouping of the gallery forest described also in an association: the Synsepaletum cerasiferum ass. nov. The two associations are overlapped thus in a succession that forms the nowadays Kouoghap sacral forest.

\section{Conflict of interest statement}

Authors declare that they have no conflict of interest.

\section{Acknowledgement}

This work was supported by Biodiversity Conservation Organization 420 Riddles Drive. Strong Collins. CO. 80521 (970) 482-6748. www.ideawild.org Tax ID: 83-0299770, that offered some facilities. Thanks too for Mr. Nchia Ntam Lawrence Fya for editing.

\section{References}

Aubreville, A. (Ed.) \& coll. Multiples, 1961-1999. Floraof Gabon. National Museum of Natural History, PhanerogamyLaboratory, Paris, Vol. 1 (1961) at 35 (1999).

Aubreville, A. (Ed.) \& coll. Multiples, 1963-1998. Flora of Cameroon. National Museum of Natural History, Phanerogamy Laboratory, Paris, Vol. 1 (1963) at 34 (1998).

Aubréville, A., 1959. Forest flora of the Ivory Coast ( $2{ }^{\text {nd }}$ edition). Publ. CTFT, Nogent. 3 Volumes, $370 \mathrm{p}+342 \mathrm{p}+334 \mathrm{p}$.

Aubréville, A., 1964. Sapotaceae. Flora of Cameroon 2. Ministry of Scientific Research. Yaounde. 143 p.

Boquet, G., Aeschimann, D., 1981. A change in the classification of biological forms of Ellemberg \& Mueller-Dombois. Candollea. 36, 271-278.

Braun-Blanquet, J., 1932. Plant Sociology. The Study of Plant Communities. McGray Hill, New York, London. 439p.

Chipp, T. F., 1927. The Gold Coast forest. A Study in Synecology. Oxford For Mem 7, Oxford, 94p.

Danserau, P., Lems, K., 1957. The grading of dispersal types in plant communities and their Ecological significance. Contrib. Inst. Bot. Univ. Montréal. 71, 52p.

Ducret, G., 1990. Extra-Wall Activity Report on Bafoussam. Academic Center of Dschang, 
Document 2, pp.1-15.

Ellemberg, H., Mueller-Dombois, D., 1967. A key to Raunkiaer life-forms with revised subdivisions. Ber. Geobot. Inst. Stifing Rübel Zürich. 37, 56-73.

Evrard, C., 1968. Ecological Research on the Forest Stand of Hydromorphic Soils in the Central Congolese Basin. Scientific Series 110 INEAC, Bruxelles, 295p.

Fosso, J., 1999. Volcanology, Petrography and Geochemistry of One Stratovolcan of the High Plateaus of the West Cameroon. Doctorate $3^{\text {rd }}$ cycle thesis, University of Yaounde I, 196p.

Hallé, N., 1966. Rubiaceae ( $1^{\text {st }}$ Part). Vol. 12. Firmin DIDOT, Paris.

Hill, M, O., 1994. DECORANA and TWINSPAN, for Ordination and Classification of Mutivariate Species Data: A New Edition, together with Supporting Programs, in FORTRAN 77. TABLEFIT programs (Ed.), Huntingdon England, 58p.

Hoff, M., Brisse, H., Grandjouan, G., 1983. The ruderal and anthropic vegetation of New Caledonia and Loyalty Islands (South Pacific). Phytosociol. Conf. 12, 179-248.

Hoff, M., Brisse, H., 1983. Proposal for a synthetic scheme of intertopical secondary vegetation. Phytosociol. Conf. 12, 249-267.

Koechlin, J., Trochain, J. L., 1955. On the existence of a forest postclimax by means of Congo. CRAc Sci. 241(1), 329-331.

Kuété, M., 1977. Geomorphological study of the Yaounde massif. $3^{\text {rd }}$ Cycle thesis, Bordeaux. 279p.

Lebrun, J. P., Gilbert, G., 1954. An ecological classification of the forests of the Congo. Publ. INEAC, 89p.

Lebrun, J. P. S., Stork, A. L., 1191, 1992, 1995, 1997. Introduction of the Flowering Plants of Tropical Africa. 4 Volumes. Editions of the Conservatories and Garden Botanies of the city of Geneva, Switzerland.

Leeuwenberg, A., 1965. Specimens collected in the locality of Eseka, South of the Nyong river andat 200m altitude, in the primary forest of Songbong. National Herbariumof Cameroon. \#7351/1965-12-15.

Letouzey, R., 1968. Cameroon phytogeographic study. Encycl. Biol., (Ed.: P. Lechevalier), Paris, $511 \mathrm{p}$.

Letouzey, R., 1985. Notice of the phytogeographic map of Cameroon at 1: 500 000. 2. Afromon- tagnard region and submontagnard stage. Institute of the international vegetation mapIRA (National Herbarium), Yaounde, Cameroon. 61p.

Madiapevo, S. N., 2008. Study of the diversity and the structure of the woody plant of the submountain forest of the Kala mount (1156m), region of Yaounde. Memory of DEA, University of Yaounde I, 71p.

Mangenot, G., 1955. Study on the forests of the plains and the plateaus of the Ivory Coast. Studyeburn. 4, 5-81.

Njiki, W. D., 1984. Geological study of the region of Bangou. Master thesis, Faculty of Science, University of Yaoundé, 59p.

Normand, M. D., 1965. Identification of the trees and the woods of the main forest species in the Centrafrican Republic. CTFT Nogent-surMarne, 78p.

Noumi, E., 2008. Didacticsof life and earth sciences illustrated by examples and docimology: Teacher's manuel for high schools and colleges. Yaoundé: Edition GIC ICSSC. (Reprography).

Noumi, E., Amougou, A., 2003. Crassulescent thicket submountainat Euphorbia kamerunica of the Minloua Inselberg (Yaoundé, Cameroon). J. Cam. Acad. Sci. 3(3), 185-201.

Noumi, E., 1998. The «transition forest» at Garcinia spp. The Nkolobot hill (region of Yaounde). Belg, J. Bot. 130(2), 198-220.

Noumi, E., 2012. Ligneous flora diversity of a submountain forest of West Cameroon: The Kouoghap sacral forest of the village Batoufam. J. Ecol. Nat. Environ. 4(1), 8-28.

Noumi, E., 2013. Floristic inventory of woody species in the Manengouba mountain forest, Cameroon. J. Biol. Life Sci. 4(2), 282-309.

Noumi, E., 2015. Floristic structure and diversity of a tropical sub-mountaneous evergreen forest, in the Mbam Minkom Massif (Western Yaounde). J. Biol. Life Sci. 6(1), 149-193.

Nzenti, J. P., Ngako, V., Kambou, R., Penaye, J., Bassahak, J., Njem, O. U., 1992. Regional structures of the Pan-African chain of North Cameroon. C R Acad. Sci. Paris. 315(2), 209215.

Raunkiaer, C., 1934. The Life-forms of Plants. Clarendron Press, Oxford, 632p.

Schmitz, A., 1963. Overview of plant groups in Katanga. Bull. Soc. Roy. Bot. Belg. 96, 233-447. Schmitz, A., 1988. Revision of the described plant 
groups in Zaire, in Rwanda and in Burundi. Belgique, Publ. C D A T, Mus. Roy. Afr. Centr. Tervuren, 315p.

Schnell, R., 1970. Introduction to the Phytogeography of the Tropical Countries: The General Problems 1. Gauthier-Villars, Paris, 499p.

Schnell, R., 1971. Introduction to Phytogeography of Tropical Countries. Vol. II: Environments, Plat Groups. Gauthier-Villars, Paris, 951p.

Shannon, C. E., Weaver, W., 1949. The Mathematical Theory of Communication. Urbana Univ. Press, Illinois, pp.117-127.

Suchel, J. B., 1972. Rainfall distribution and rainfall regime in Cameroon. Contribution to the study of tropical African climates. Trav. and Doc. of Tropical Geography. 5 Univ. Fed. Cam., Bordeaux, France. Ed. C E G T, 287p.

Tagne, T. G. A., 2007. Floristic and structural study of the ligneous flora of the submountain forest of the Messa hill (Yaoundé). Memory of DEA thesis, Univercity of Yaounde I, 66p.

Taylor, C. J., 1960. Synecology and silviculture in Ghana, Accra and London. 406p.

Tchoua, F., 1974. Contribution to the geological and petrographic study of some volcanoes of Cameroon line (Mounts Manegouba and Bamboutos). Thesis Doc. State, University of Clermond-Ferrand, 347p.

Tchoua, T. J. M., 2013. Phytogeographical study of the Mount Kupe submountain storey (Moungo, Cameroon). Memory of Master thesis, University of Yaounde 1, 5op.

Tüxen, R., Preising, E., 1942. Grunbegriffe und methoden zum studium der Wasser und sumflanzengesellschaften. Deutsche Wasserwirtschaft. 37, 10-17; 57-69.

Vivien, J., Faure, J. J., 1985. Trees of the dense forests of Cantral Africa. ACCT Paris, 565p.

Walter, H., Lieth, H., 1964. Klimadiagram Weltatlas. G. Fischer, Jena.

White, F., 1983. The vegetation of Africa. A descriptive memory to accompagny the UNESCO/AETFAT/UNSO vegetation map of Africa. Natural Resources Research 20, UNESCO, Paris, 356p.

Zenker, G. A., 1898. Specimens collected in the locality of Bipendi. National Herbarium of Cameroon. \#1569/1898-10-1.

\section{How to cite this article:}

Makemteu, J., Noumi, E., 2020. Characterization of plant groups and description of plant succession in the sacred Kouoghap forest of the Batoufam village, West Cameroon. Int. J. Curr. Res. Biosci. Plant Biol. 7(4), 14-36. doi: https://doi.org/10.20546/ijcrbp.2020.704.003 